\title{
La construcción de los paisajes del Palacio Real de Madrid, Siglos XVI-XX
}

\author{
Pilar Chías Navarro \\ Tomás Abad
}

Resumen

La elección de la privilegiada ubicación del Palacio Real en Madrid se remonta a la Edad Media, cuando a finales del siglo IX se construyó el viejo Alcázar en el borde de las terrazas del río Manzanares con el fin de dominar visual y militarmente todos los territorios circundantes en un radio de más de siete leguas (más de cuarenta kilómetros). La primitiva fortaleza árabe fue reedificada en el siglo XIV por los reyes de Castilla, y empezó a convertirse en la residencia real a partir del primer tercio del siglo XV. En I 56 I la capital del Reino y la corte, hasta entonces itinerantes, se trasladaron a Madrid por decisión del rey Felipe II, y la Villa se convirtió en el centro de un entramado territorial de residencias reales vinculadas a la caza y el ocio de los reyes, que siguieron utilizándose en su mayoría hasta 1864 , año en el que se produjo su enajenación o su uso público. En consecuencia, desde mediados del siglo $\mathrm{XVI}$ se sucedieron cambios en el paisaje urbano del entorno del Palacio, así como en los bosques y los jardines del conjunto palacial. Reconstruir los paisajes en cada periodo histórico con una distancia temporal de cinco siglos es el objetivo principal e innovador de nuestra investigación, y para ello nos hemos basado en el análisis comparado de la numerosa documentación gráfica y escrita existente.

Palabras clave

reales sitios, paisajes, España, ss. XVI-XX, distancias.

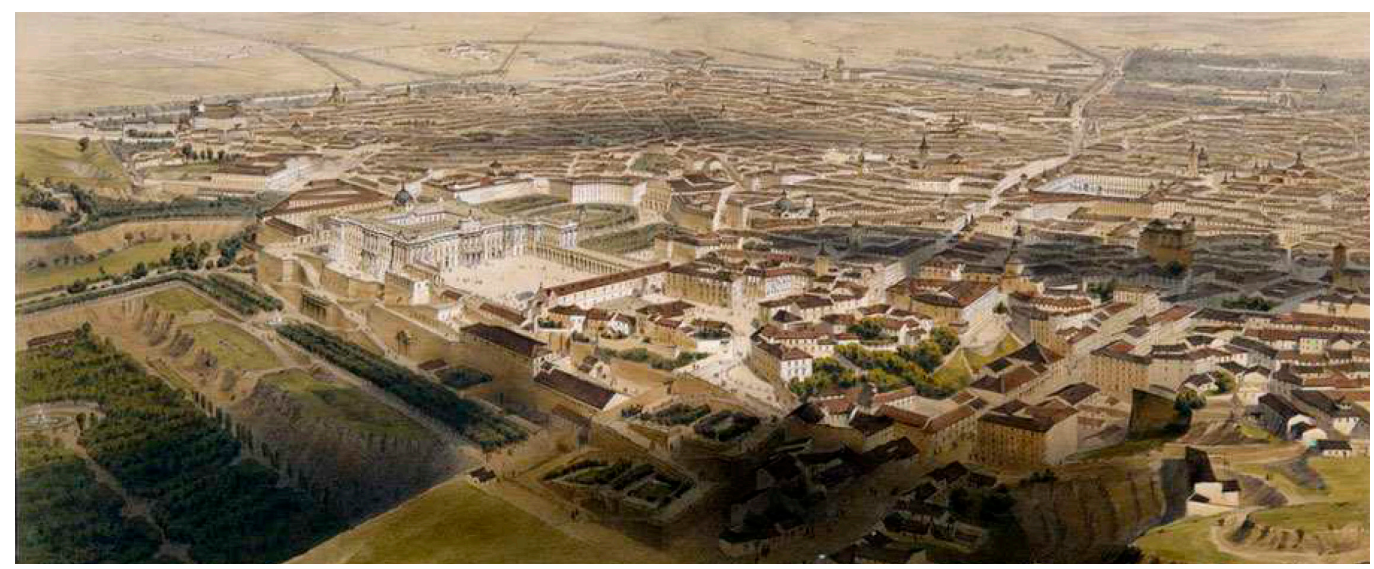




\section{Introducción}

Desde el siglo IX está documentada la existencia de una fortaleza árabe o Alcázar situada en el borde de las terrazas fluviales del Manzanares. Su ubicación respondía a la necesidad de dominar visual y militarmente un vasto territorio que alcanzaba por el Norte la Sierra de Guadarrama, y por el Sur llegaba hasta Toledo y Aranjuez, ambas a orillas del río Tajo. Una vez reconquistados estos territorios, el Alcázar se convirtió en un apeadero eventual de los reyes de Castilla, cuya corte era itinerante. Reedificado en el siglo XIV, hasta el primer tercio del siglo XV no fue utilizado como residencia real. Pero la verdadera transformación en Palacio se inició en | 56 |, cuando Felipe II decidió fijar la capital del Reino y la Corte en Madrid, que era una población medieval encerrada por murallas (fig. I).

La investigación que presentamos aborda los cambios en el paisaje del entorno del Palacio acaecidos a partir del traslado de la Corte a Madrid en I56I hasta el comienzo de la Guerra Civil, en 1936. Para ello no sólo hemos localizado y estudiado la importante documentación gráfica empleada, sino que a partir de los puntos de vista más frecuentemente utilizados hemos identificado los principales hitos paisajísticos y los emplazamientos de los principales proyectos, construidos o no.

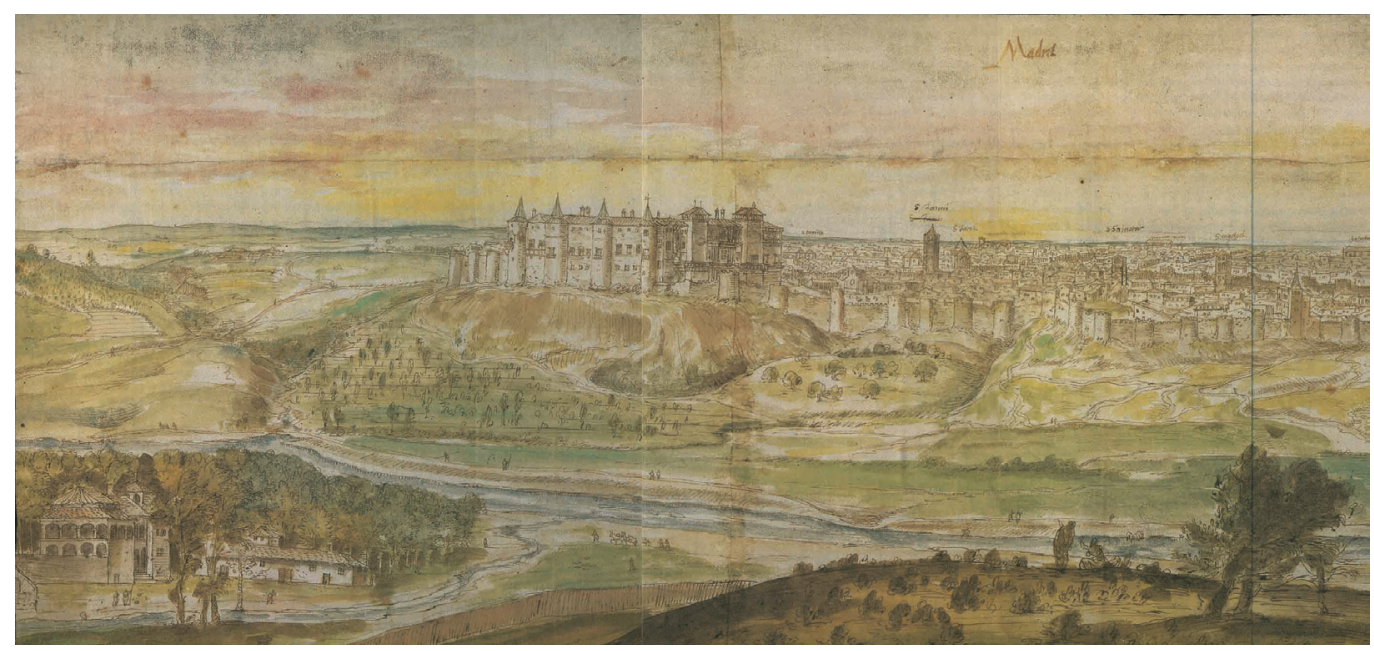

\section{Objetivos y precedentes}

La principal aportación al avance en el conocimiento es el estudio de la construcción de los sucesivos paisajes del entorno urbano y de los bosques y jardines que fueron surgiendo en torno al primitivo Alcázar de Madrid, y siglos después, alrededor del Palacio Real Nuevo. El objetivo es recuperar la memoria histórica de tales paisajes, y recuperar los vestigios que aún subsisten para preservarlos y contextualizarlos, no sólo desde el punto de vista histórico, sino en el marco de una escala geográfica más amplia que la que proporciona la arquitectura o la arqueología.

Los estudios sobre las transformaciones en el paisaje urbano a lo largo de la historia son numerosos, como se recogió en las actas del Convegno AED de 2002 [Mandelli, Duvernoy 2002], en las investigaciones de Centofanti, Romolo, Gianfranco, Brusaporci y Trizio (2008), y en las metodologías expuestas en Cundari y Carnevali (2003); entre los estudios más recientes cabe citar las líneas de investigación de Vernizzi y Bontempi (20 I5), de Giandebiaggi y Vernizzi (2020), y de Luschi y Aiello (2020). Sobre los Reales Sitios en Europa, merecen citarse las aportaciones de Papa y D'Agostino (2020) y de Corniello (2019). En el ámbito territorial, citaremos las investigaciones sobre el uso de las modernas tecnologías de la información de De Marco y Dell’Amico (2020). 
Este estudio constituye un paso más en la línea de investigación sobre la construcción del territorio y del paisaje que vienen desarrollado los autores desde hace más de dos décadas, y en particular en el ámbito de los Reales Sitios españoles [Chías 2019; Chías, Papa 2019; Chías, Abad 2016; Chías, Abad 20 I8; Chías, Abad 2019a; Chías, Abad 20l 9b; Chías, Abad 2019c; Chías, Abad 202I], por citar sólo las contribuciones más recientes.

Existen numerosos estudios sobre aspectos concretos de esta zona de Madrid, de los que citaremos sólo algunos de los más recientes que inciden en el entorno urbano del Palacio [Sancho 1988; Sancho 1995; Sancho 20 I5; Martínez 2008].

Fig. 2. Antonio Joly, Vista de Madrid, c. 1762 . Palazzo Reale, Napoli.

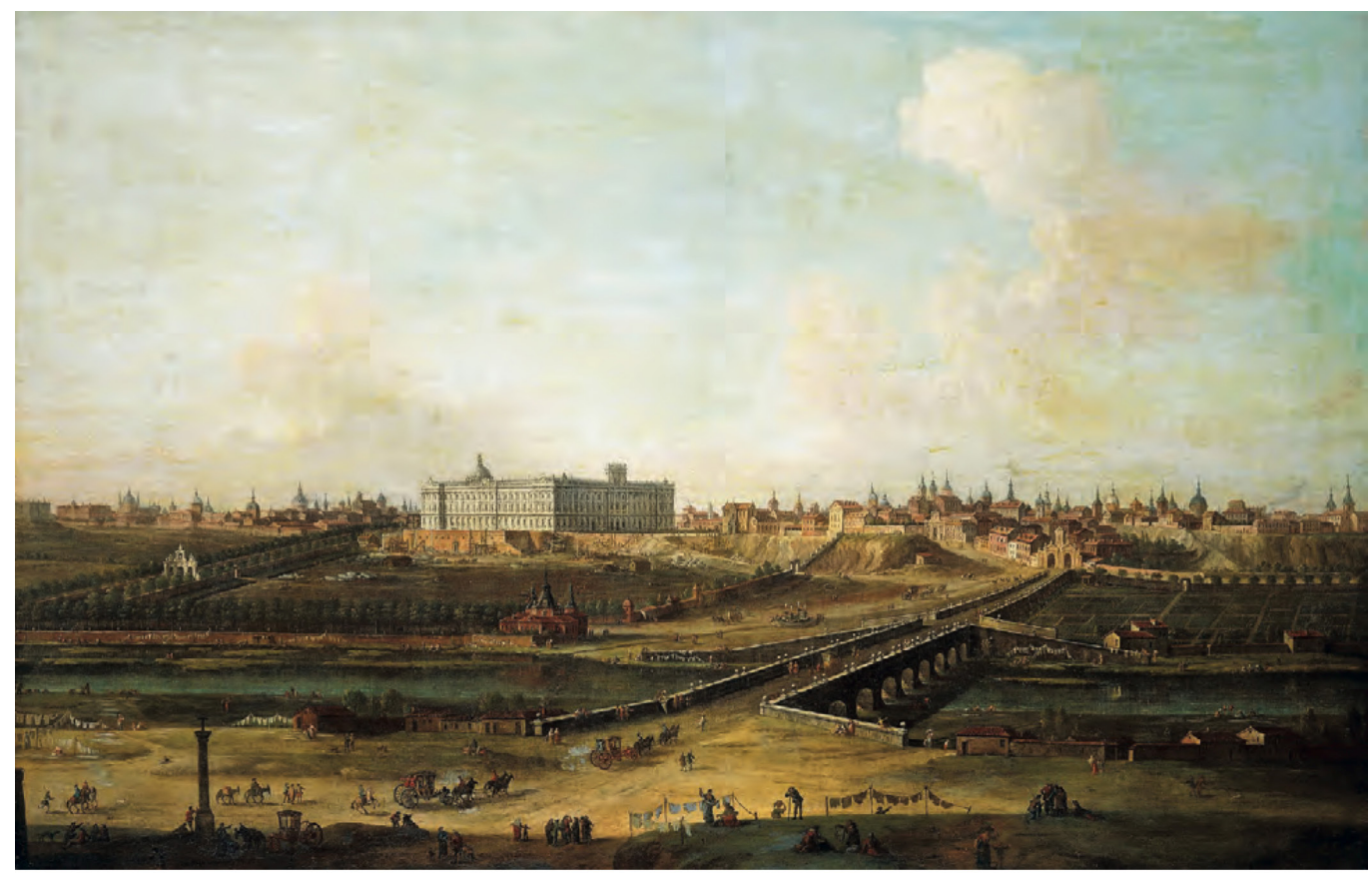

\section{Metodología}

Para desarrollar el estudio hemos establecido un marco temporal que se extiende a lo largo de dos etapas históricas que cubre cada una un periodo de dos siglos:

- La primera abarca el reinado de los Habsburgo desde I544, cuando empezó a haber constancia documental de las primeras mejoras realizadas en el Alcázar y en su entorno [Gérard 1976], hasta la Nochebuena de 1734, fecha del pavoroso incendio que destruyó el edificio.

- La segunda se extiende a lo largo de los reinados de los Borbones desde los proyectos y construcción del Palacio Real Nuevo en 1735, hasta 1935, cuando en plena República el destacado arquitecto y urbanista Fernando García Mercadal llevó a cabo la demolición de las antiguas caballerizas situadas al norte del Palacio, y construyó en su lugar los Jardines de Sabatini para su uso público.

El ámbito geográfico de la investigación se extiende por el Este hasta la Plaza de Oriente y el Teatro Real, prestando especial atención a los proyectos de Silvestre Pérez bajo el breve reinado de José I Bonaparte. Por el Sur, llega desde la Plaza de la Armería hasta la iglesia de San Francisco el Grande y se centra en las distintas soluciones en viaducto que se proyectaron para salvar la vaguada de la calle de Segovia. Por el Norte, llega hasta la cuesta de San Vicente y la Plaza de España; y por el Oeste, abarca la Casa de Campo y el Campo del Moro, ocupado sucesivamente por huertas, cazaderos, sembrados y jardines, así como los importantes puentes históricos trazados por renombrados arquitectos como Juan de Herrera, Patricio Caxés y Pedro de Ribera (fig. 2). 
Para ello, en una primera fase hemos localizado y estudiado la numerosísima documentación gráfica, cartográfica, fotográfica y escrita existente, que abarca más de cinco siglos y que se conserva fundamentalmente el Archivo y la Real Biblioteca de Palacio, el Archivo Municipal de Madrid y la Biblioteca Nacional de España. Una parte importante de este conjunto documental está compuesto por las memorias de los proyectos arquitectónicos del edificio, de sus anejos y de su entorno urbano, incluyendo aquellos no realizados pero que llegaron a condicionar la formación de los espacios urbanos del entorno del Palacio. Existen numerosas descripciones escritas realizadas por viajeros, artistas y literatos españoles y extranjeros de todas las épocas -Antonio Ponz (1776-1794), George Sand ( | 854- | 857), Richard Ford ( 845$)$, entre muchos otros- e incluso el Palacio ha sido el escenario de novelas como las de Benito Pérez Galdós (1884) y de crónicas como las de Ramón Mesonero Romanos (|86|).

En una segunda fase hemos realizado un análisis comparado de la información contenida en las distintas fuentes, con el fin de identificar cada hito paisajístico y contextualizarlo en su momento histórico. Así mismo hemos investigado las pautas que se aplicaron en su diseño, y los sucesos y decisiones que condicionaron su posterior evolución.

A modo de ejemplo, las tres figuras que adjuntamos y que distan en el tiempo trescientos años, muestran el perfil urbano desde puntos de vista muy próximos, situados al otro lado del río Manzanares. En todos ellos el Palacio ocupa una posición dominante, pero también son fácilmente identificables numerosos hitos urbanos: el puente y la calle de Segovia, las Caballerizas de Felipe II, la Puerta de la Vega, la ermita de la Virgen del Puerto, y los campanarios y cúpulas de las numerosas iglesias que existen en la ciudad, etc. (figs. I -3). Las imágenes que recogen los usos y las funciones de los espacios arquitectónicos y urbanos son también muy abundantes. Muestran tanto la vida cotidiana de los madrileños como los actos extraordinarios celebrados en la Villa y en la corte. Junto con los relatos de los contemporáneos, estas imágenes gráficas resultan especialmente ilustrativas de cómo se utilizaron esos espacios y de los aspectos protocolarios que influyeron en muchos casos en su diseño (fig. 4).

Fig. 3. Charles Clifford, Madrid visto desde el oeste, c. I860. Biblioteca Nacional de España, Madrid.

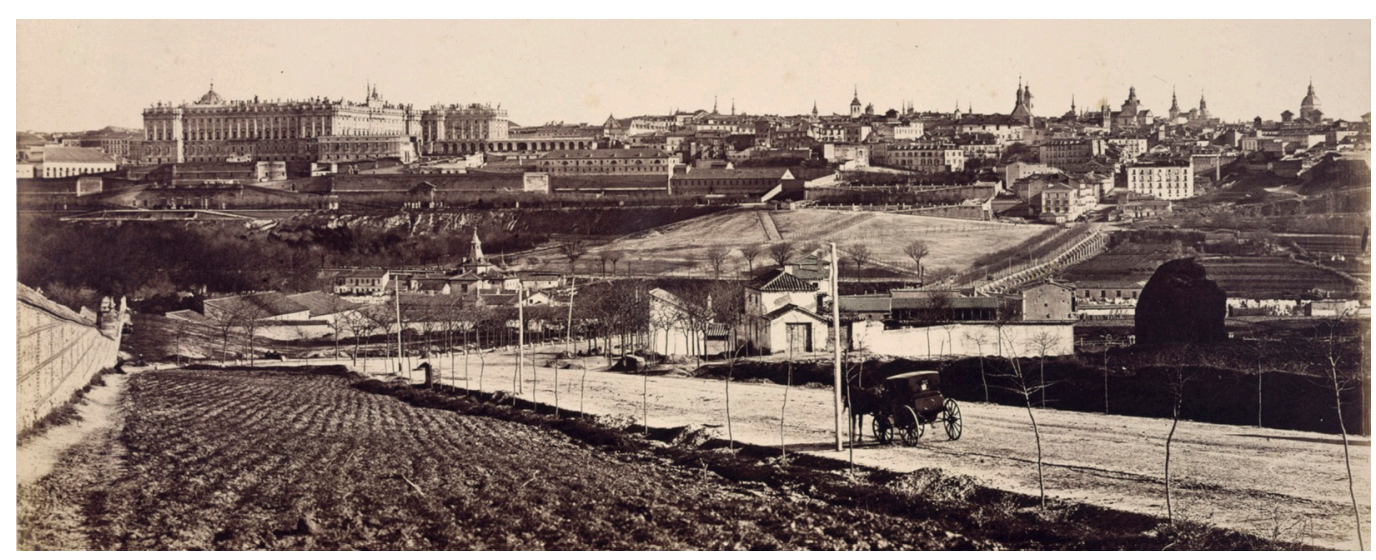

\section{Los principales hitos en la construcción del paisaje del Palacio y de su entorno}

Entre 1550 y 1700 los reyes españoles de la dinastía Habsburgo ampliaron las estancias palaciegas y reformaron la fachada principal y la Plaza de Palacio, para dotar al edificio de un carácter simbólico con la necesaria proyección institucional como sede del poder real (fig. 4).

En paralelo se llevó a cabo una reorganización de los jardines, que se situaron al Norte y al Este del Alcázar, manteniendo próximos los "jardines secretos" y un poco más alejados 
Fig. 4. Filippo Pallotta, Aclamación del Rey Nuestro Señor Don Phelipe V por la coronada Villa de Madrid el día XXIV de noviembre de MDCC [... 1700. Museo de Historia de Madrid.
Fig. 5. Teodoro Ardemans, Orthographia de el Real Alcazar de Madrid (det.), nale de France, Paris.

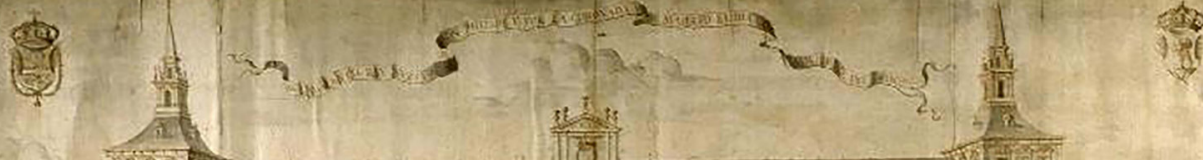

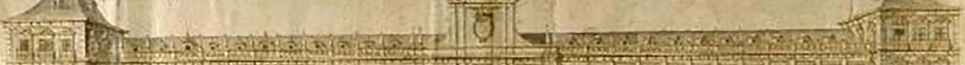

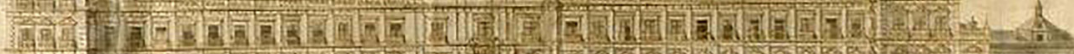

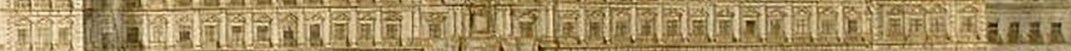

ल0

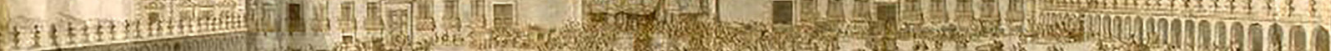

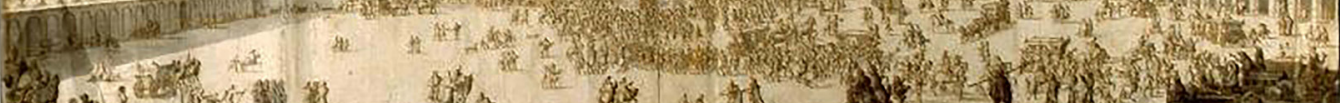

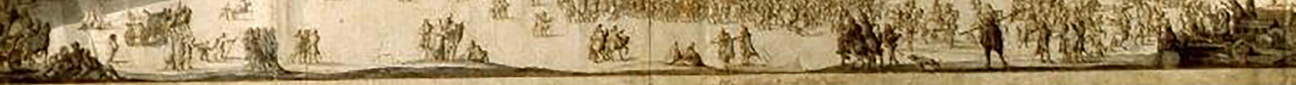

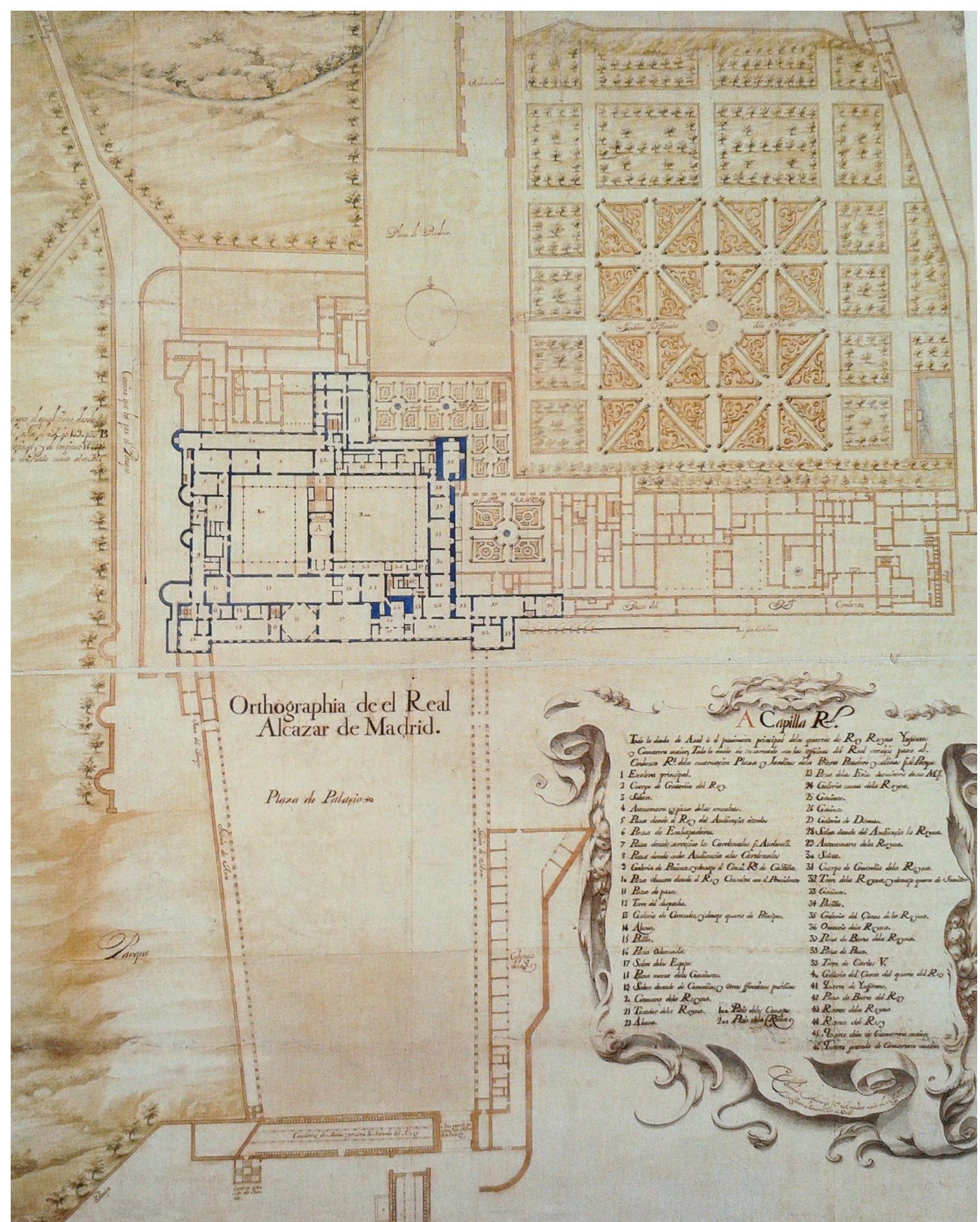


Fig. 6. Giovanni Battista Sacchetti, Sección transversal de las bajadas al Parque, 1757. Archivo General de Palacio, Palacio Real, Madrid y con mayor extensión, los Jardines de la Priora (fig. 5). A su vez, el Camino que va al Parque descendía al río para comunicar el Palacio con la Casa de Campo y con los bosques circundantes, que se utilizaban como cazaderos.

Hacia poniente existe un desnivel de más de 60 m que el Palacio Real Nuevo trató de salvar por medio de una rampa piranesiana. Ésta permitía el tránsito de caballerías, sillas de mano y carriolas, con precedentes en el Pozzo di San Patrizio de Orvieto -obra de Antonio di Sangallo, 1527-1537, y en el pozo de la Ciudadela de Turín (fig. 6).

En el entorno urbano se abrieron y alinearon nuevas calles -como la de las Platerías-, se construyeron puentes sobre el río en las principales salidas de la ciudad, y se trazaron y regularizaron nuevos espacios urbanos -como la vieja Plaza del Arrabal, convertida en Plaza Mayor de la Villa (fig. 7).

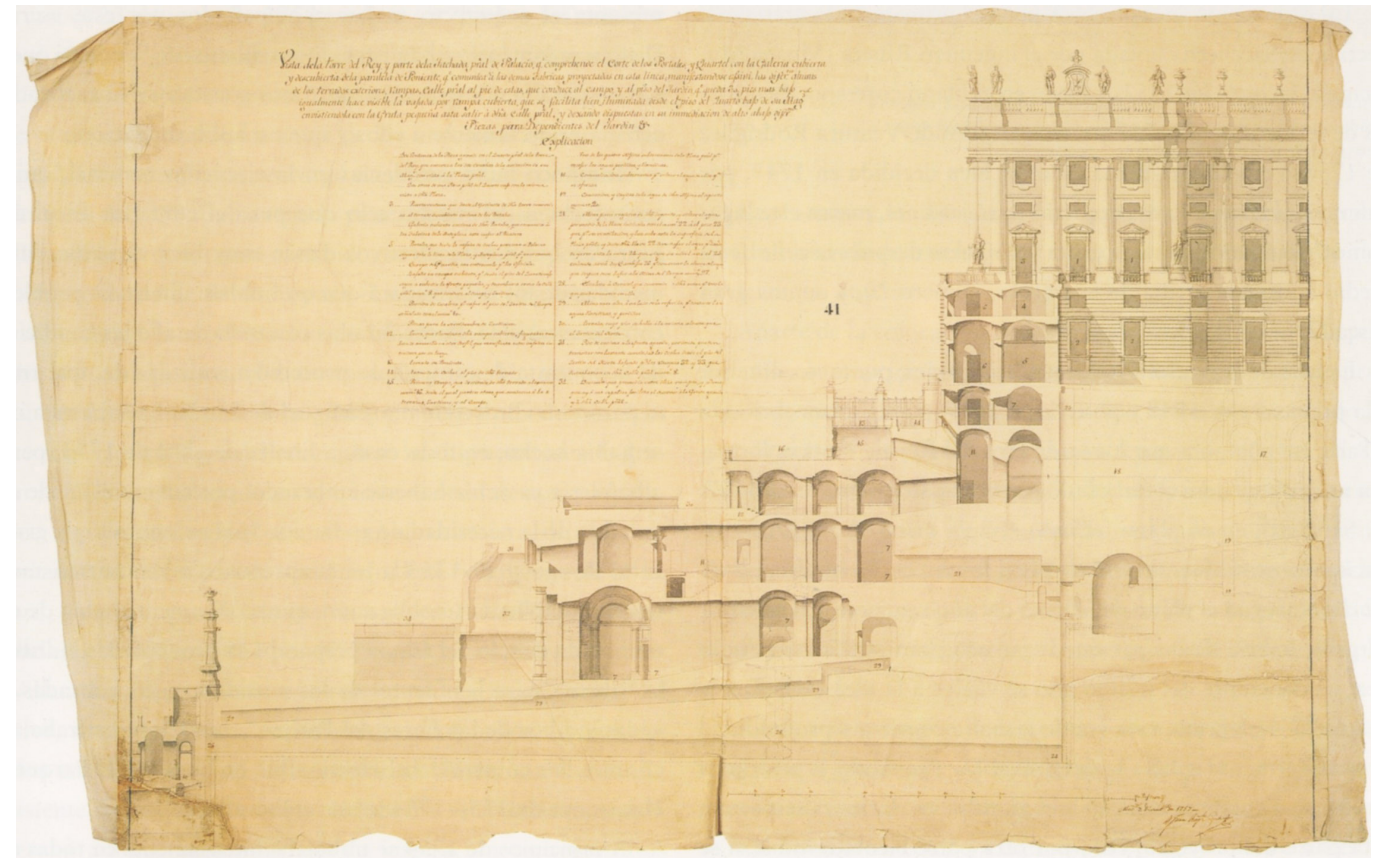

Los reyes de la dinastía Borbón mantuvieron su residencia en el antiguo emplazamiento del Alcázar, pero el incendio de éste en la Nochebuena de 1734 impuso la construcción de un nuevo palacio más acorde a los nuevos gustos barroco-clasicistas.

El proyecto fue encargado por el rey Felipe $V$ a Filippo Juvarra en 1735, que propuso un edificio con un gran desarrollo horizontal en planta. Por su extensión se habría tenido que construir en otra terraza fluvial situada unos $400 \mathrm{~m}$ al norte (fig. 8).

El rey decidió que el Palacio Real Nuevo se ubicara en el mismo lugar que antes ocupaba el Alcázar, por lo que una vez fallecido el arquitecto encargó a su discípulo Giovanni Battista Sacchetti la adaptación del edificio a una organización vertical dentro de un bloque compacto. Francesco Sabatini, que había colaborado con Juvarra en el espectacular Palazzo Reale di Caserta, también fue llamado para intervenir en la adaptación del proyecto de su maestro a los cambiantes gustos de los monarcas (fig. 9).

Por supuesto, el nuevo palacio, "quizás el mayor y más suntuoso de todos los de Europa", en palabras de Richard Twiss ( 1775 ), mantuvo su carácter central dentro del sistema de Reales Sitios que se habían ido construyendo en torno a la corte.

Los proyectos urbanos más interesantes que se propusieron entonces para el entorno del Palacio Nuevo se concentraron en: las Plazas de Oriente y de Armas, con las consiguientes demoliciones de las construcciones existentes; en la evolución de la zona de La Tela y de los jardines del Campo del Moro y su conexión con la plataforma del Palacio (figs. 6-9); y en otras actuaciones destinadas a salvar la accidentada topografía del entorno del Palacio, incluyendo el viaducto (fig. I0). 
Fig. 7. Pedro Texeira, Modrid (det), 1656 Biblioteca Nacional 656 España, Madrid.

Fig. 8. Filippo Juvarra Sección longitudinal por la escalera principal y la capilla, del proyecto para el Palacio Real Nuevo de Madrid, c. 1735. Biblioteca Nacional de España,

Madrid.

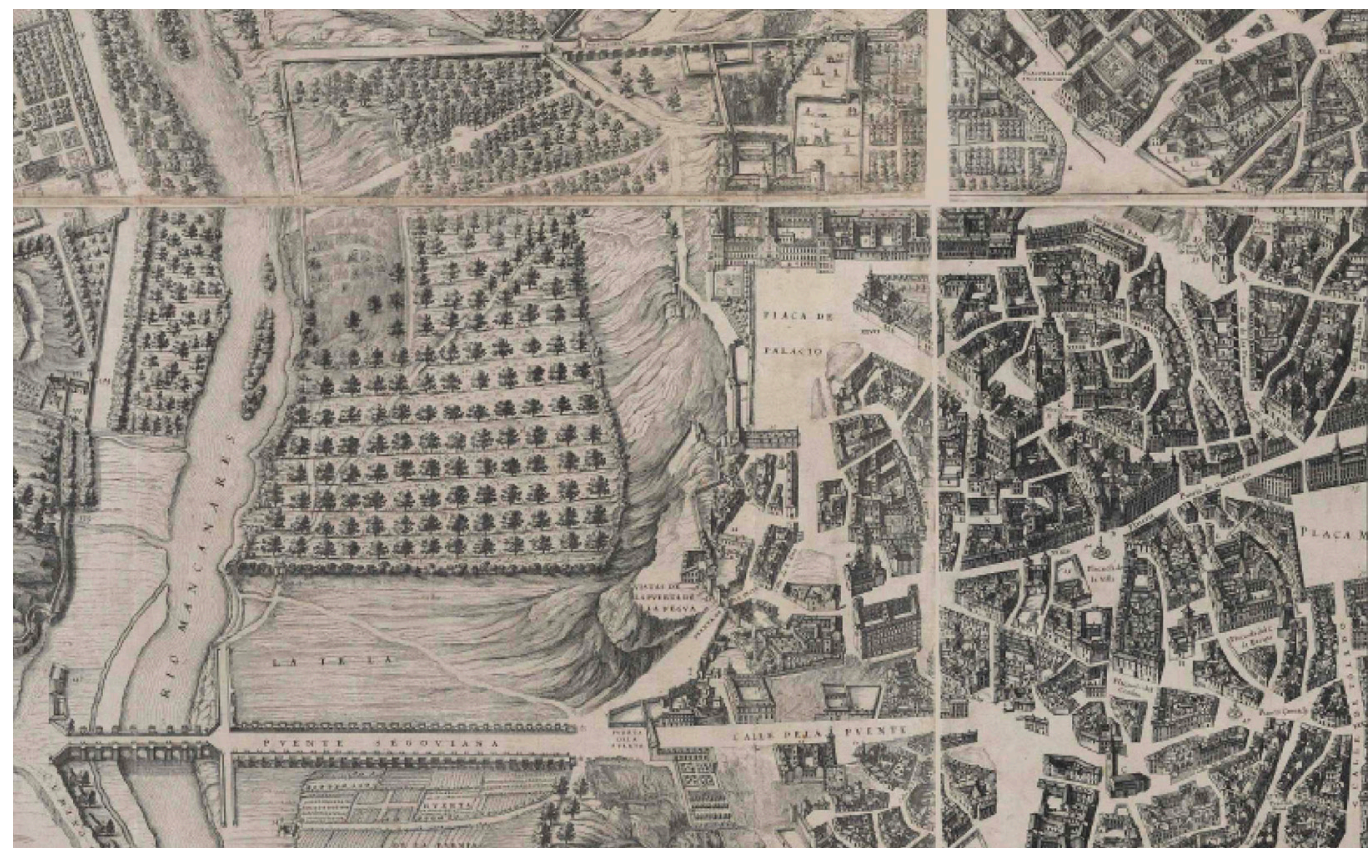

Con el exilio de los reyes en 1931 se impuso un cambio de carácter en el diseño de los jardines y de los espacios exteriores del entorno del palacio, que hasta entonces habían sido de uso exclusivo de la familia real. La demolición de las caballerizas permitió construir los Jardines de Sabatini con un uso público que aún se mantiene y es cuidadosamente preservado por Patrimonio Nacional [Chías 20 I7] (fig. I I).

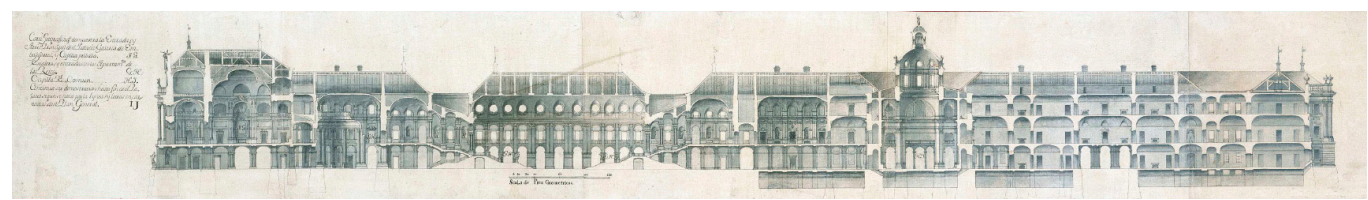

\section{Conclusiones y prospectiva}

La reconstrucción de los procesos de formación de estos paisajes constituye un instrumento esencial y previo a cualquier actuación que se vaya a realizar en ellos, si se quiere evitar borrar la memoria histórica del territorio.

Para ello, y como instrumento de conocimiento y de gestión, toda la información se está integrando en un Sistema de Información Geográfica (SIG) estructurado por capas, implementado sobre una base cartográfica digital a escala 1:2.000. En él se han diferenciado los distintos tipos de elementos e hitos del paisaje, cuyos datos se han recogido en las correspondientes bases de datos multiformato que incluyen tanto datos gráficos como escritos y multimedia.

Un Modelo Digital del Terreno (MDT) nos va a permitir reconstruir las cuencas visuales desde los puntos de vista más frecuentes en las imágenes históricas y en cada periodo estudiado, y proponer otras que muestran las cualidades de los espacios urbanos más significativos, proyectados o desaparecidos. 
Fig. 9. Fachada oeste del Palacio Real Nuevo hacia el Campo del Moro.

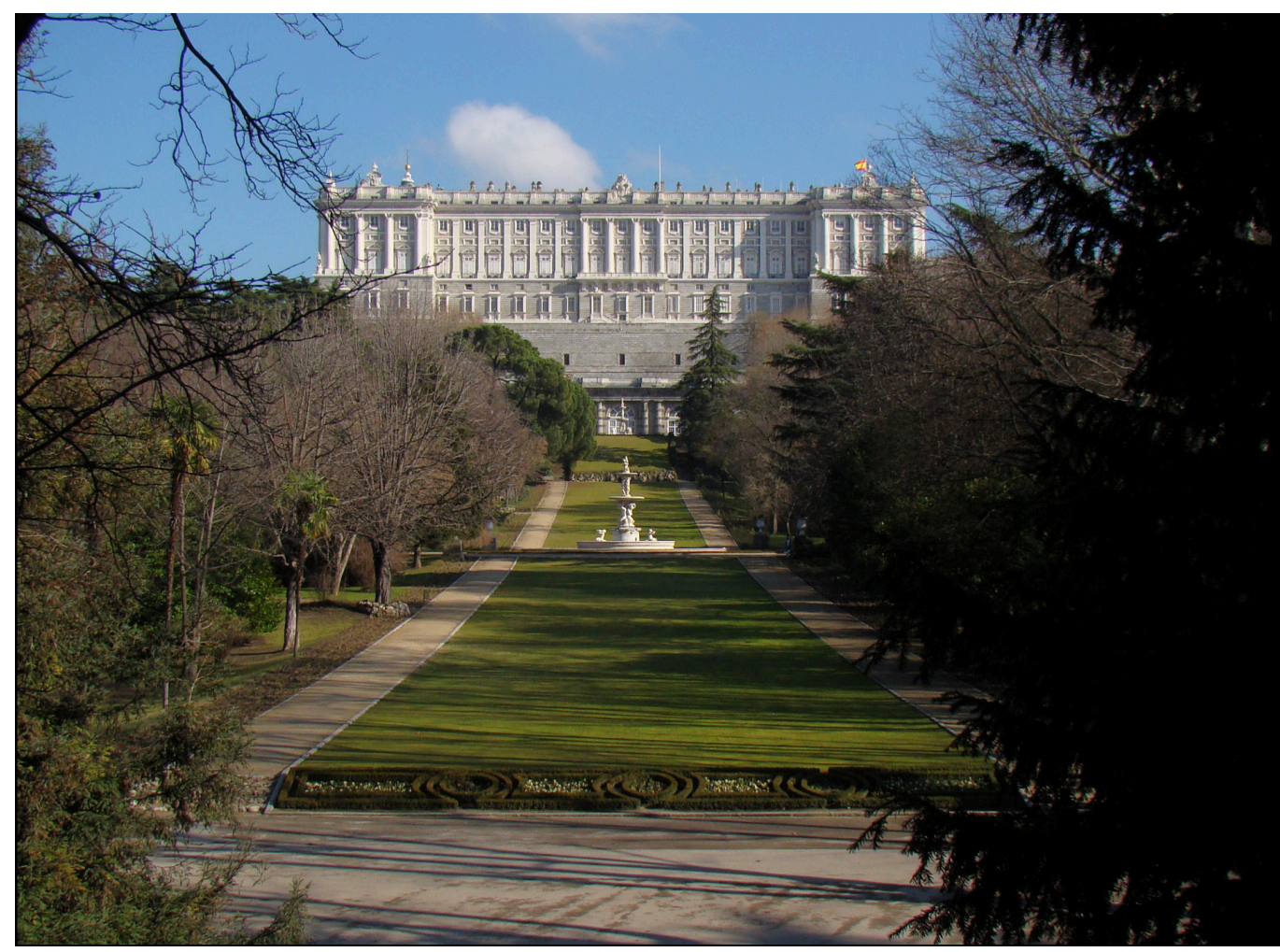

Fig. 10. Silvestre Pérez, Plan de ordenación del entorno del Palacio Real y 18 bario de San Francisco. de España, Madrid.

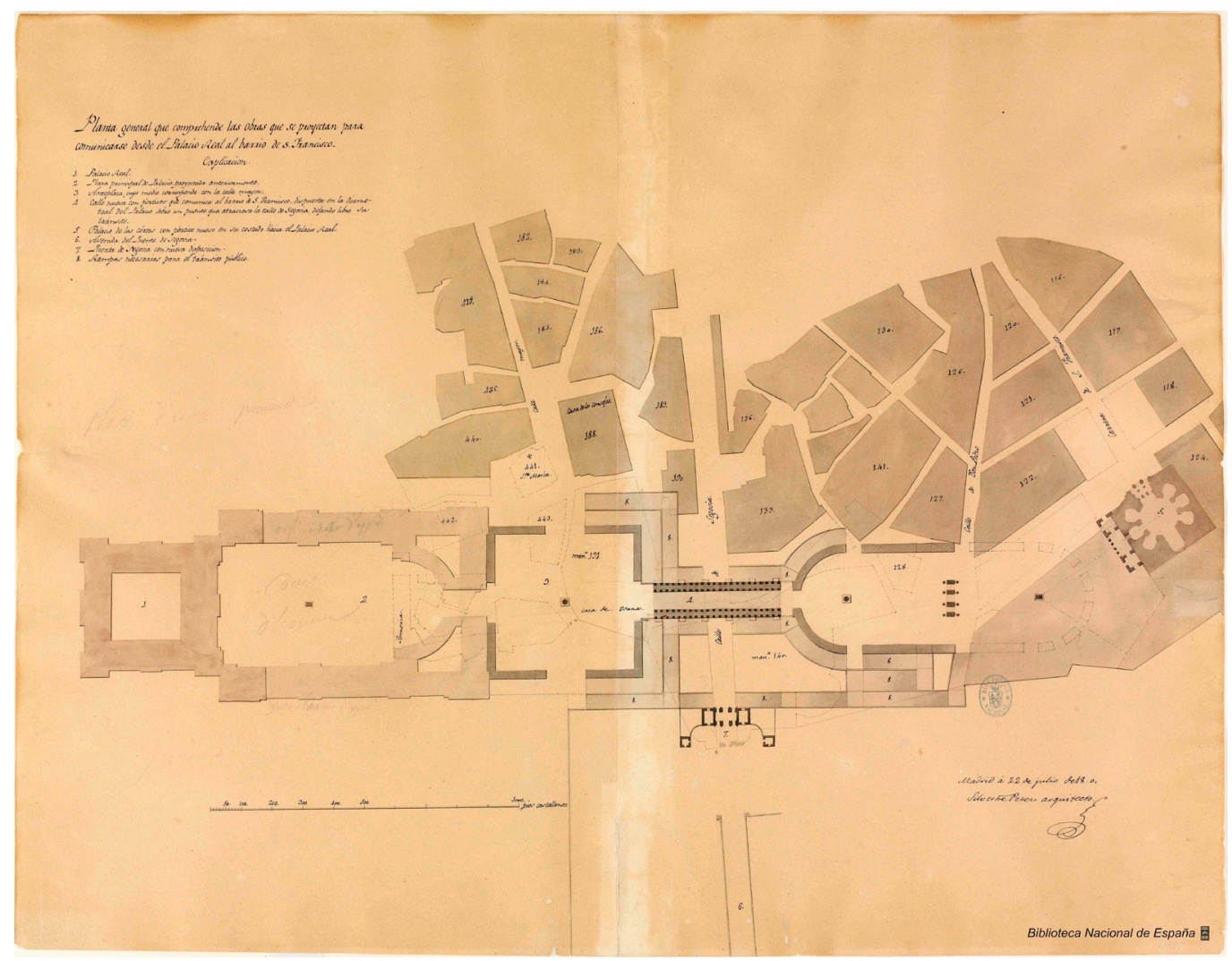


Fig. I I. Fernando García Mercadal, Proyecto de jardín para el Palacio Naciona. Arquitectura, 1934. En Revista del Colegio Oficia de Arquitectos, n. 8, 1935

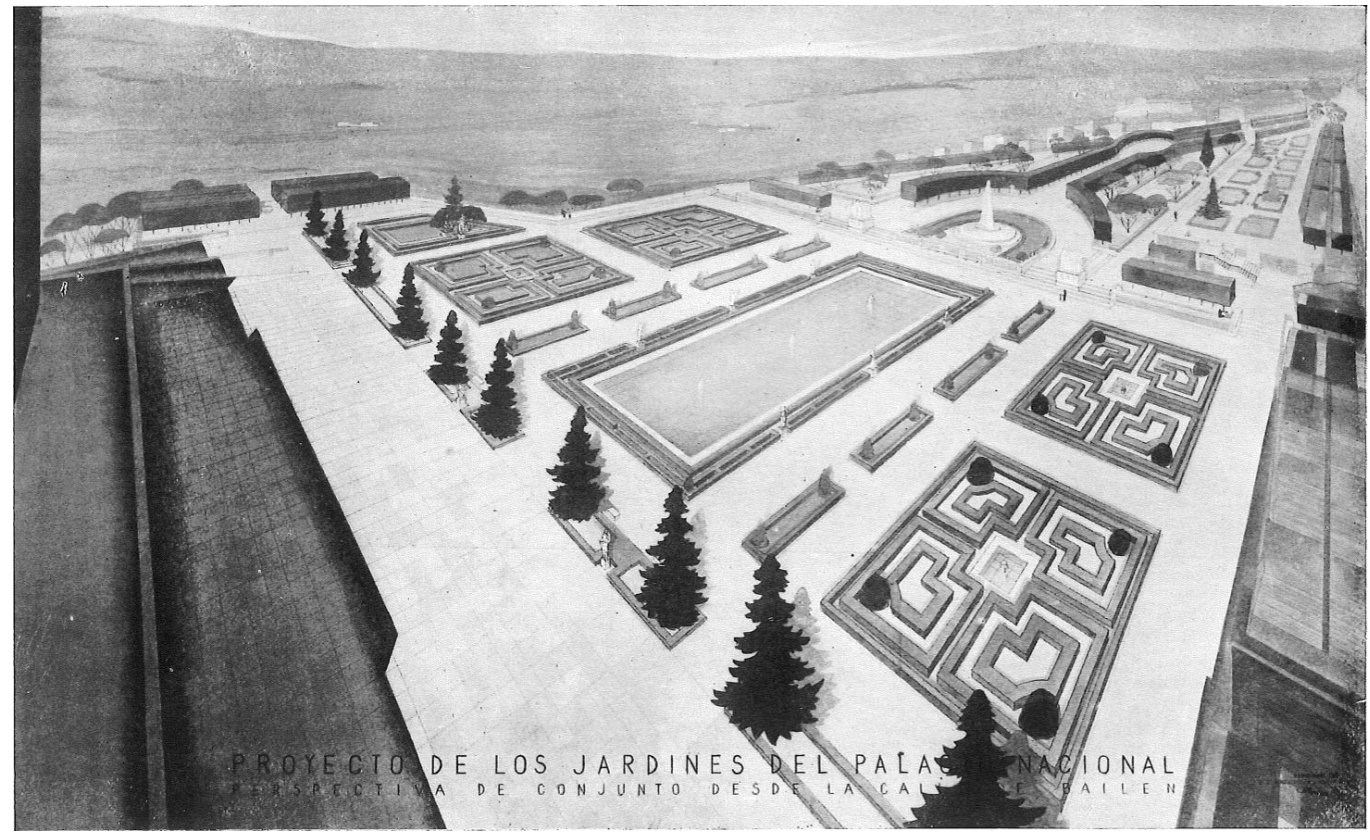

\section{Referencias}

Bianchini C. et al (2020). La costruzione scientifica della memoria: il caso della nuova antica cittá di Ninfa. En A. Arena et al (a cura di). Connettere/Connecting. Un disegno per annodare e tessere/Drawing for weaving relationships. Atti del $42^{\circ}$ Convegno Internazionale dei Docenti delle Discipline della Rappresentazione/Connecting. Languages Distances Technologies. Proceedings of the $42^{\text {th }}$ International Conference of Representation Disciplines Teachers. Milano: Franco Angeli, pp. I 760 - 1777.

Centofanti M. et al. (2008). II progetto del SIARCH - UNIVAQ, Sistema Informativo Architettonico. En R. Mingucci, M. Centofanti (a cura di). DisegnareCon, Conservazione del Patrimonio Architettonico e Urbano, n. I (2), pp. I-7.

Chías P. (20 I7). Complejidad y contradicción en el urbanismo de Fernando García Mercadal. En Academia, n. 3, pp. 22 I-236.

Chías P. (2019). Building territories and landscapes: the essential knowledge of a forgotten cultural heritage. En IMG Journal. 05/0I, pp. 92-105.

Chías P., Abad T. (2016). La transformación de la topografía y del paisaje en la construcción del Monasterio de El Escorial. En Informes de la Construcción. 68/543, pp. I-12.

Chías P., AbadT. (2018). Drawings and scale models used in building the Spanish royal sites. En Diségno, n. 2, pp. 33-42.

Chías P., AbadT. (2019a). Maps and Drawings of the Royal Sites around the Guadarrama Mountain Range. En Revista EGE. I I, pp. 44-63.

Chías P., AbadT. (20 /9b). Building territories and landscapes at the Royal Site of Aranjuez. En Diségno, n. 5, pp. 8I-90.

Chías P., Abad T. (2019c). La cartografía y otras fuentes gráficas para el conocimiento del territorio y del paisaje. Los Reales sitios en torno a Madrid. En CT Catastro, n. 96, pp. I I-42.

Chías P.,AbadT. (202 la). Fuentes cartográficas para el conocimiento de los territorios de los Reales Sitios. El caso de Aranjuez, 1775-1912. En Los Libros de la Corte, 22, pp. II-42.

Chías P.,AbadT. (202 I b). Fuentes cartográficas para el conocimiento de los territorios de los Reales Sitios. El caso de Aranjuez, 1775-1912. En Jiménez Castillo, J., Rivero Rodríguez, M. (coords.) De Reinos a Naciones. Espacios, territorios y mentalidades. Colección La Corte en Europa, 21. Madrid: Polifemo, 25I-299.

Chías P., Papa L. M. (a cura di). (2019). Disegnarecon. Drawing the territory and the landscape.Vol. I 2, n. 22.

Corniello L. (2019). II disegno del Parco Reale di Tirana. Napoli: La Scuola di Pitagora editrice.

Cundari C., Carnevali L. (a cura di). (2003). Il rilevamento urbano: tipologia, procedure, informatizzazione. Roma: Kappa edizioni.

De Marco R. Dell'Amico A (2020). Connettere il territorio tra patrimonio e informazione: banche dati e modelli per le Cultural Heritage routes. En A. Arena et al. (a cura di). Connettere/Connecting. Un disegno per annodare e tessere/Drawing for weaving relationships. Atti del $42^{\circ}$ Convegno Internazionale dei Docenti delle Discipline della Rappresentazione/Connecting. Languages Distances Technologies. Proceedings of the $42^{\text {th }}$ International Conference of Representation Disciplines Teacher. Milano: Franco Angeli, pp. 2058-2077. 
Ford R. (1845). A handbook for travelers in Spain and readers at home. London: John Murray, Albermarle Street.

Gérard V. (1976). Les problémes artistiques de l’Alcázar de Madrid (I537-1700). Mélanges de la Casa de Velázquez, t. Xll, pp. 307-322.

Giandebiaggi P.,Vernizzi C. (2020). Gli organismo religiosi nella trasformazione della cittá europea: dal rilievo alla definizione di una identitá urbana. En A. Arena et al (a cura di). Connettere/Connecting. Un disegno per annodare e tessere/Drawing for weaving relationships. Atti del $42^{\circ}$ Convegno Internazionale dei Docenti delle Discipline della Rappresentazione/Connecting. Languages Distances Technologies. Proceedings of the $42^{\text {th }}$ International Conference of Representation Disciplines Teacher. Milano: Franco Angeli, pp. ||6|-||82.

Luschi C. M. R., Aiello L. (2020). La ricostruzione storica della città attarvetrso l'iconografia urbana. Il caso studio di San Giovanni d'Acri. En A.Arena et al (a cura di). Connettere/Connecting. Un disegno per annodare e tessere/Drawing for weaving relationships. Atti del $42^{\circ}$ Convegno Internazionale dei Docenti delle Discipline della Rappresentazione/Connecting. Languages Distances Technologies. Proceedings of the $42^{\text {th }}$ International Conference of Representation Disciplines Teacher. Milano: Franco Angeli, pp. $2369-2382$.

Mandelli E., Duvernoy S. (2002) (a cura di). Il disegno della città: opera aperta nel tempo. Atti del Convegno internazionale AED. San Gimignano 28-30 giugno 2002. Firenze: Alinea.

Martínez A. (2008). Espacio, tiempo y proyecto: El entorno urbano del Palacio Real Nuevo de Madrid entre 1735 y I885. Madrid: Ayuntamiento de Madrid.

Mesonero Romanos R. (| $86 \mid$ |). El antiguo Madrid: paseos histórico-anecdóticos por las calles y casas de esta villa. Madrid: Establecimiento Tipográfico de Don F. de P. Mellado.

Papa M. L., D'Agostino P. (2020). Un proceso integrato di conscenza e visualizzazzione. II castello della Reggia di Portici. En A. Arena et al (a cura di). Connettere/Connecting. Un disegno per annodare e tessere/Drawing for weaving relationships. Atti del $42^{\circ}$ Convegno Internazionale dei Docenti delle Discipline della Rappresentazione/Connecting. Languages Distances Technologies. Proceedings of the $42^{\text {th }}$ International Conference of Representation Disciplines Teacher. Milano: Franco Angeli, pp. 25 I 5-2532.

Pérez Galdós B. (1884). La de Bringas. Madrid: Imp. y Lit. de La Guirnalda.

Ponz A. (1776- I794). Viage de España en que se dá noticia de las cosas más apreciables, y dignas de saberse, que hay en ella Tercera edición, 8 vols., Madrid: Por D. Joachin Ibarra.

Sancho J. L. (1988). Notas sobre la herencia de Vanvitelli en la obra de Palacio. En Actas del Congreso Internacional Carlos III y la Luis llustración. Madrid: Ministerio de Cultura.

Sancho J. L. (1995). La arquitectura de los Sitios Reales. Catálogo histórico de los palacios, jardines y patronatos reales del Patrimonio Nacional. Madrid: Patrimonio Nacional, Fundación Tabacalera.

Sancho J. L. (20 I5). Palacio Real de Madrid. Madrid: Patrimonio Nacional.

Sand G. ( 1 854- 1857). Histoire de ma vie. Vols. I0. Paris:Victor Lecou, Éditeur / Michel Lévy Fréres, Libraires.

Twiss R. (1775). Travels through Portugal and Spain, in 1772 and 1 773. London: Printed for the Author and sold by G. Robinson, T. Becket, and J. Robson.

Vernizzi C., Bontempi D. (2015). La rappersentazione della città per lo stuio dei fenomeni urbani. Evoluzione metodológica attraverso casi studio. En A. Marotta, G. Novello, (a cura di). Disegno \& Città: cultura, arte, scienza, informazione. Atti del $37^{\circ}$ Convegno Internazionale dei Docenti delle Discipline della Rappresentazione. Torino 17-19 settembre 20 I5, pp. 87I-878. Roma: Gangemi Editore.

\section{Autores}

Pilar Chías Navarro, Universidad de Alcalá, pilar.chias@uah.es

Tomás Abad, Universidad de Alcalá, tomas.abad@uah.es

Para citar este artículo: Chías Navarro Pilar,AbadTomás (2021). La construcción de los paisajes del palacio real de madrid, Siglos XVI-XX/Planned and built landscapes around the Palacio Real in Madrid, $16^{\text {th }}$ to $20^{\text {th }}$ Centuries. In Arena A., Arena M., Mediati D., Raffa P. (a cura di). Connettere. Un disegno per annodare e tessere. Linguaggi Distanze Tecnologie. Atti del $42^{\circ}$ Convegno Internazionale dei Docenti delle Discipline della Rappresentazione/ Connecting. Drawing for weaving relationship. Languages Distances Technologies. Proceedings of the $42^{\text {th }}$ International Conference of Representation Disciplines Teachers. Milano: FrancoAngeli, pp. 432-45।. 


\title{
Planned and Built Landscapes Around the Palacio Real in Madrid, $16^{\text {th }}$ to $20^{\text {th }}$ Centuries
}

\author{
Pilar Chías Navarro \\ Tomás Abad
}

Abstract

The choice of the privileged location of the Royal Palace in Madrid dates back to the Middle Ages. At the end of the 9th century the old Alcázar was built on the edge of the fluvial terraces of the Manzanares river, with the aim of dominating, both from the visual and the military point of view, the territories within a radius larger than seven leagues. The former fortress was rebuilt in the $14^{\text {th }}$ Century and transformed into the Royal residence from the first third of the $\mid 5^{\text {th }}$ Century. Until I56 I the capital city of the Spanish Kingdom and the court were itinerant, but this year they moved to Madrid by decision of King Philip II.The city became the center of a wide territorial network of Royal palaces that were used for leisure and hunting activities by the royal family until I864. From the I6th century hence, successive changes in landscape ensued, affecting the surrounding woods and gardens, but also the neighbouring quarters of the old town. To this end and as a main innovation of our research, we reconstructed all these landscapes on the distance, by means of a comparative analysis of the existing written and graphic documents.

Keywords

royal sites, landscapes, Spain, $16^{\text {th }}-20^{\text {th }}$ centuries, distances.

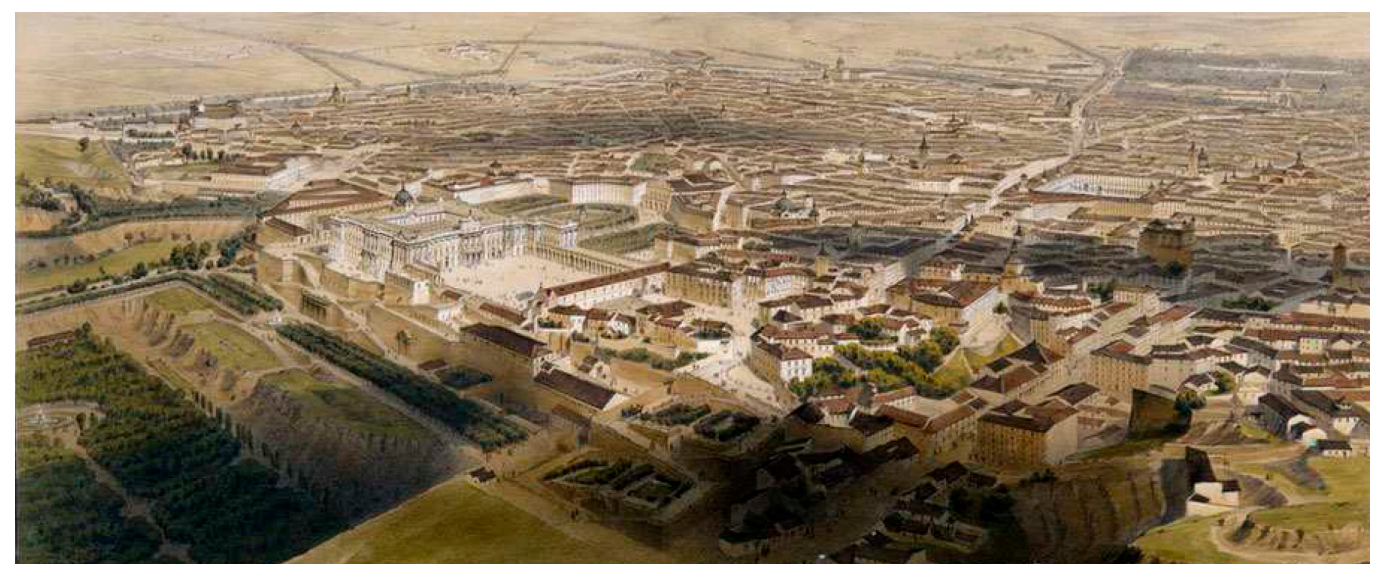




\section{Introduction}

The existence of a Muslim fortress or Alcázar at the top of the fluvial terraces of river Manzanares is dated as early as the $9^{\text {th }}$ century. Its location was justified by the need of visual and military control of the vast surrounding territories that reached the Guadarrama Mountains in the North and the Tajo river to the South. Once they were conquered, the Alcázar became a temporary lodging for the kings of Castile and their itinerant courts. Extended in the $14^{\text {th }}$ century, about I 440 it began to be used as a royal residence. But the main refurbishment started in I 56 I when King Philip I| decided to establish the capital of the Kingdom and the court in Madrid, that was a Medieval town encircled by ancient walls (fig. I).

Our research describes and analyses the changes that took place in the environment of the Royal Palace in Madrid between I56I and 1936, when the Spanish Civil War broke out.To this end, we searched exhaustively for graphic and written documents in the main archives and libraries, looking for the landmarks of each era and the location of the most interesting architectural, garden and urban projects, even unbuilt.

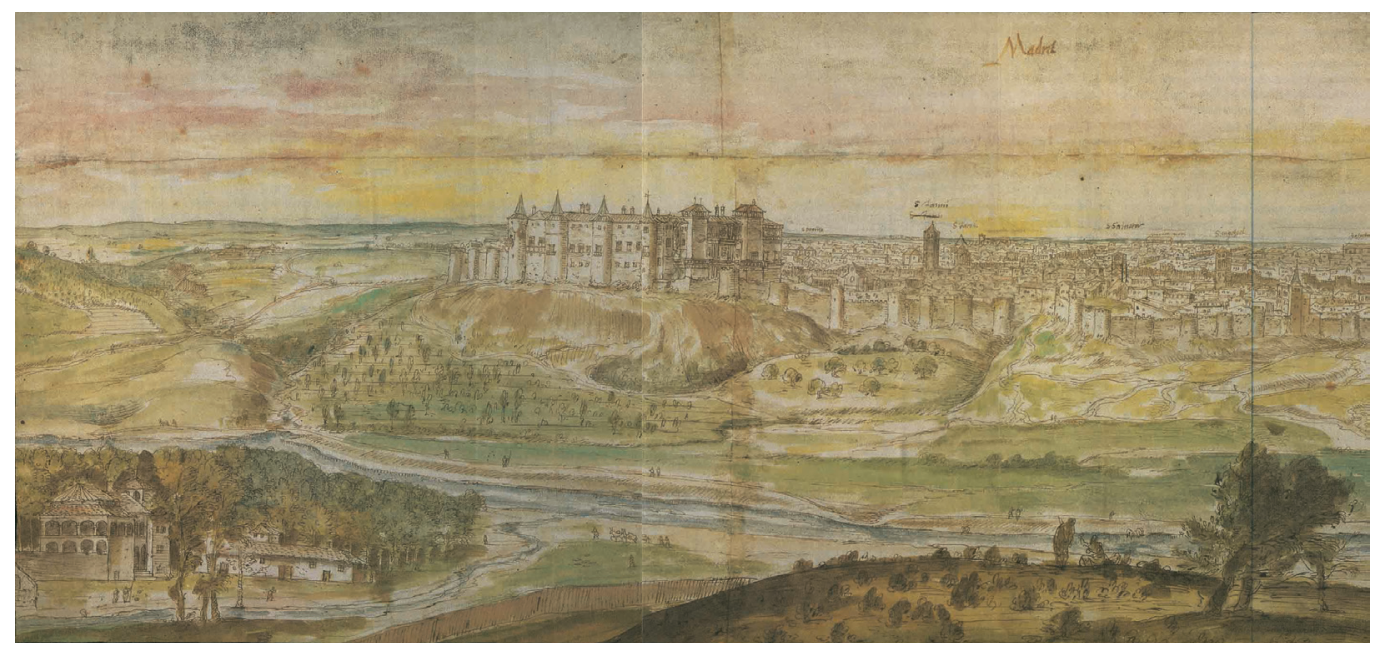

\section{Objectives and precedents}

Our major contribution to the advance of knowledge is the study of landscape construction around the former Alcázar and around the Royal Palace at a later stage. The main target is to recover the memory of such landscapes, and to find and contextualise the still existing traces in order to preserve them. Such contextualisation is developed from both the historical and the geographical point of view, providing a wider perspective that overcomes architecture and archaeology.

Studies on urban landscape transformation along history are numerous, as summarized in the AED Congress de 2002 [Mandelli, Duvernoy 2002], as well as in the research developed by Centofanti, Romolo, Gianfranco, Brusaporci and Trizio (2008), and the methodologies described by Cundari and Carnevali (2003). Among the most recent studies, those by Vernizzi and Bontempi (20 I5), Giandebiaggi and Vernizzi (2020), and Luschi and Aiello (2020), must be stressed. About the European Royal Sites, research by Papa and D'Agostino (2020), and Corniello (2019) are outstanding. With regard to the territorial scale, the use of the new information technologies is specially considered by De Marco and Dell'Amico (2020). 
The current research is a step forward in our main research line on the construction of territories and landscapes, and particularly on the Spanish Royal Sites [Chías 20 I9; Chías, Papa 20 19; Chías, Abad 2016; Chías, Abad 2018; Chías, Abad 2019a; Chías, Abad 2019b; Chías, Abad 2019c; Chías, Abad 202I ], just to cite the most recent contributions.

There are many precedents on the study of the Royal Palace in Madrid. Focusing on its urban surroundings we need to mention the works by Sancho [Sancho 1988; Sancho I995; Sancho 20I5] and Martínez (2008).

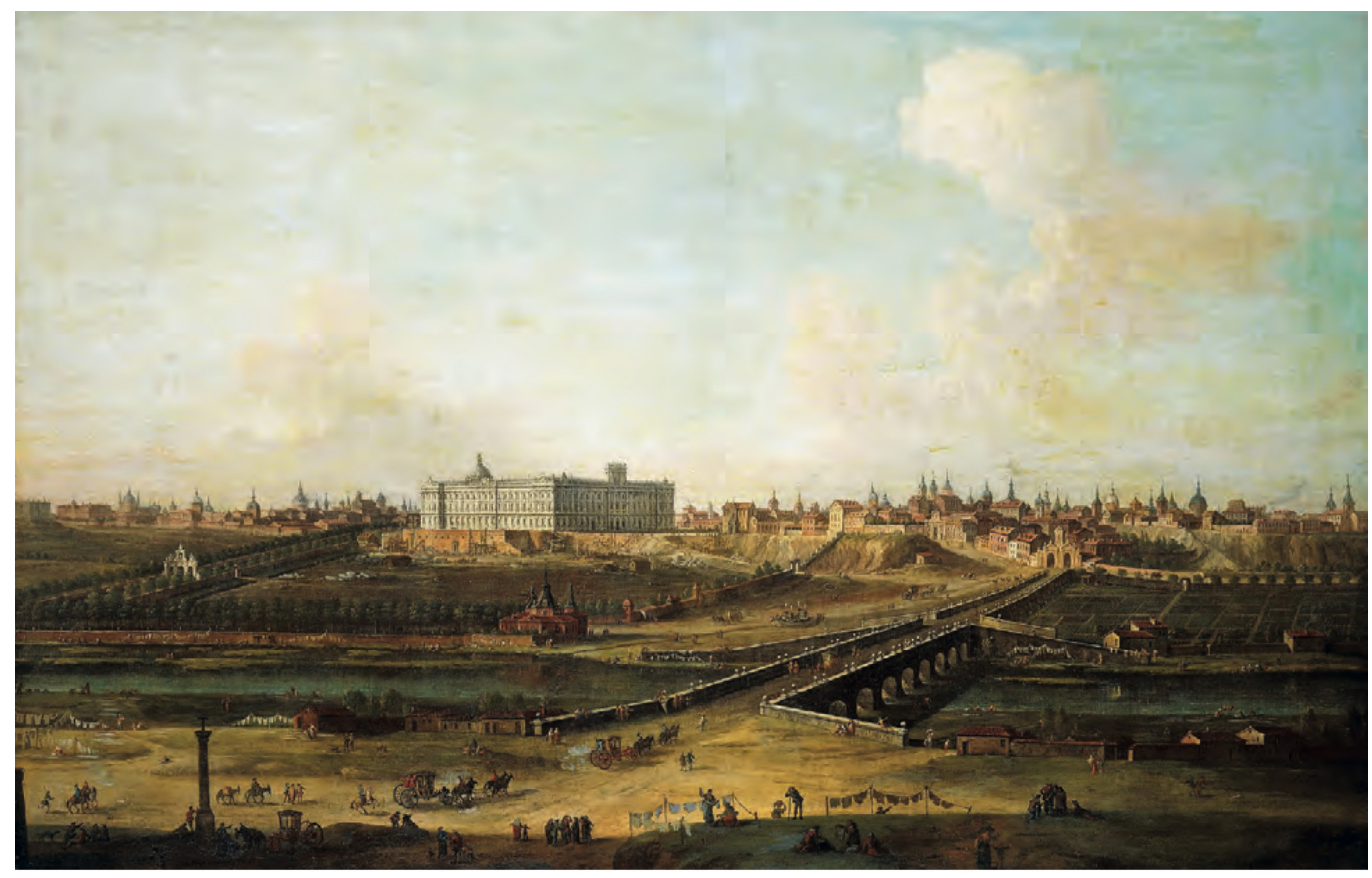

\section{Methodology}

We defined a temporary framework that extends along two historical periods covering each two centuries:

- The first one starts in 1544, when the first pieces of news about the refurbishment of the Alcázar were dated (Gérard 1976) and ends on Christmas Eve 1734, when the building burnt up.

- The second period goes from 1735 to 1936 and corresponds to the reign of the Bourbon monarchs until the end of the Second Republic. In this era the New Royal Palace was designed, built, transformed and enlarged, and following the exile of King Alphonse XIII, some interesting garden projects -Sabatini Gardens- were developed for public use.

The geographical area covered by the research extends to the East until the Royal Theatre, paying a special attention to the Plaza de Oriente and the various designs made by Silvestre Pérez for King José I Bonaparte. To the South, our research extends from the Plaza de la Armería to the church of San Francisco el Grande, focusing on the different solutions proposed to bridge Segovia Street. To the North, our study reaches the Cuesta de San Vicente and Plaza de España. And the riverbanks, the bridges -some of them designed by outstanding architects as Juan de Herrera, Patricio Caxés and Pedro de Ribera-, Casa de Campo and Campo del Moro are integrated in the study area at the western side of the Palace (fig. 2). As we mentioned before, from a methodological perspective our research on the reconstruction of historical landscapes is based on the study and comparison of the numerous existing graphic and written sources, which show the evolution of the Royal Site and its en- 
vironment for far more than five centuries. There is a huge amount of graphic, cartographic and photographic documents related to the study area, that are mainly kept in the Archivo and the Real Biblioteca de Palacio, the Archivo Municipal de Madrid and the Biblioteca Nacional de España. Most of them correspond to reports included into architectural and urban projects. But there are also many written descriptions by Spanish and foreign travelers, artists and writers of all times -Antonio Ponz ( I776- I 794), George Sand (I 854- I 857)Richard Ford (I 845), among other.

The Royal Palace was also the scenery for outstanding novels as those by Benito Pérez Galdós (I 884) and became the player of chronicles as those by Ramón Mesonero Roma$\operatorname{nos}(|86|)$.

At a second phase we analysed and compared the information brought to light by these documents, that permitted us to identify each landmark and to place it in its historic context, as well as to look for its design guidelines and its evolution. But they also helped us to follow the tracks of projects that never were built, and to find out the changes and enlargements undergone by spaces and constructions.

By way of example, the three figures provided in the paper show the cityscape as seen from three points of view that are close to each other and located on the other side of the Manzanares river, where the Alcázar and then the Royal Palace are placed in a prominent position (figs. I-3).

Other graphic and written sources that describe how the architectural and urban spaces were used along the centuries. Thus, the daily life of the inhabitants of the capital city together with the extraordinary events and the court ceremonies was recorded by artists, writers and travelers. All of them contributed to shape the urban spaces and the façades, but also the garden and the indoor spaces design (fig. 4).

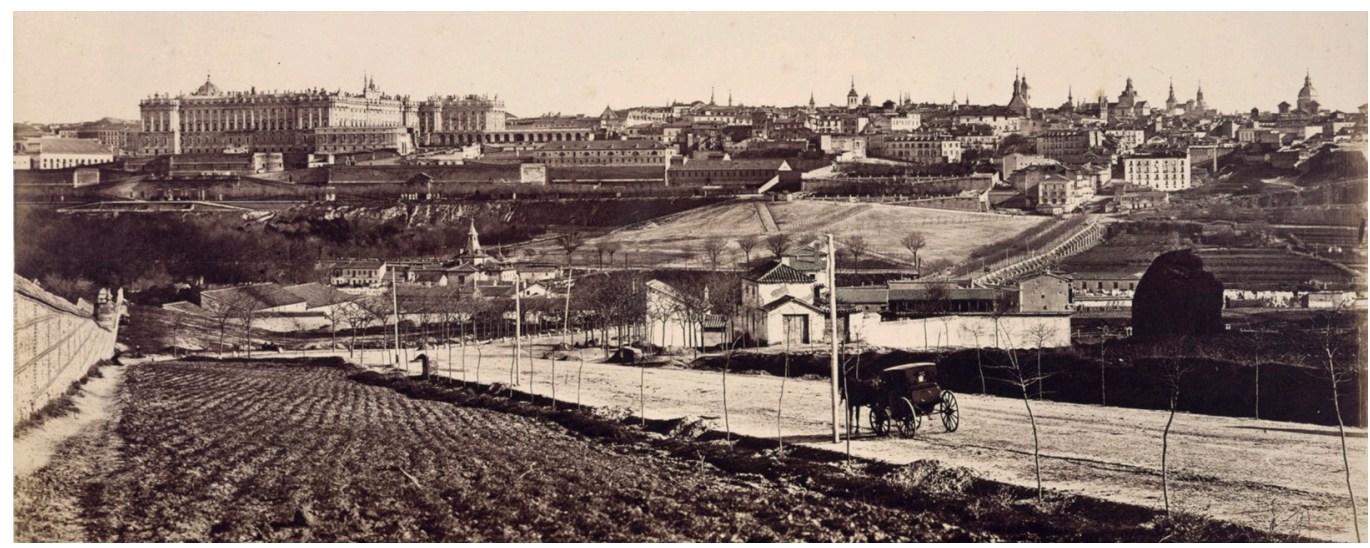

\section{Main landmarks in the construction of the landscapes of the Royal Palace and its surrounding estates}

Between 1550 and 1700 the successive Spanish kings of the Habsburg dynasty extended the palace and built a new façade, in order to give the palace its essential symbolic character as the seat of the Kings' power (fig. 4).

In parallel, the gardens were reorganized at the North and East areas outside the Alcázar. The secret gardens were kept close to the main building, while the Gardens of the Priora extended towards the North-East (fig. 5). The road leading to the Park descended to the riverside and communicated the Royal Palace with the Casa de Campo and the neighbouring woods, that were used for hunting.

The existing difference in height between the Campo del Moro and the Plaza de Armas was bridged by means of a "Piranesian" ramp, whose precedents were the Pozzo di San 
Fig. 4. Filippo Pallotta, Acclamation of King Philip $\checkmark$ by the crowned Villa of Madrid, November 24, 700 [...], 1700. Museo de Historia de Madrid.
Fig. 5. Teodoro Ardemans, Main elevation of the Roya Alcazar in Madrid (det). 1705. Bibliothèque Nationale de France, Paris.
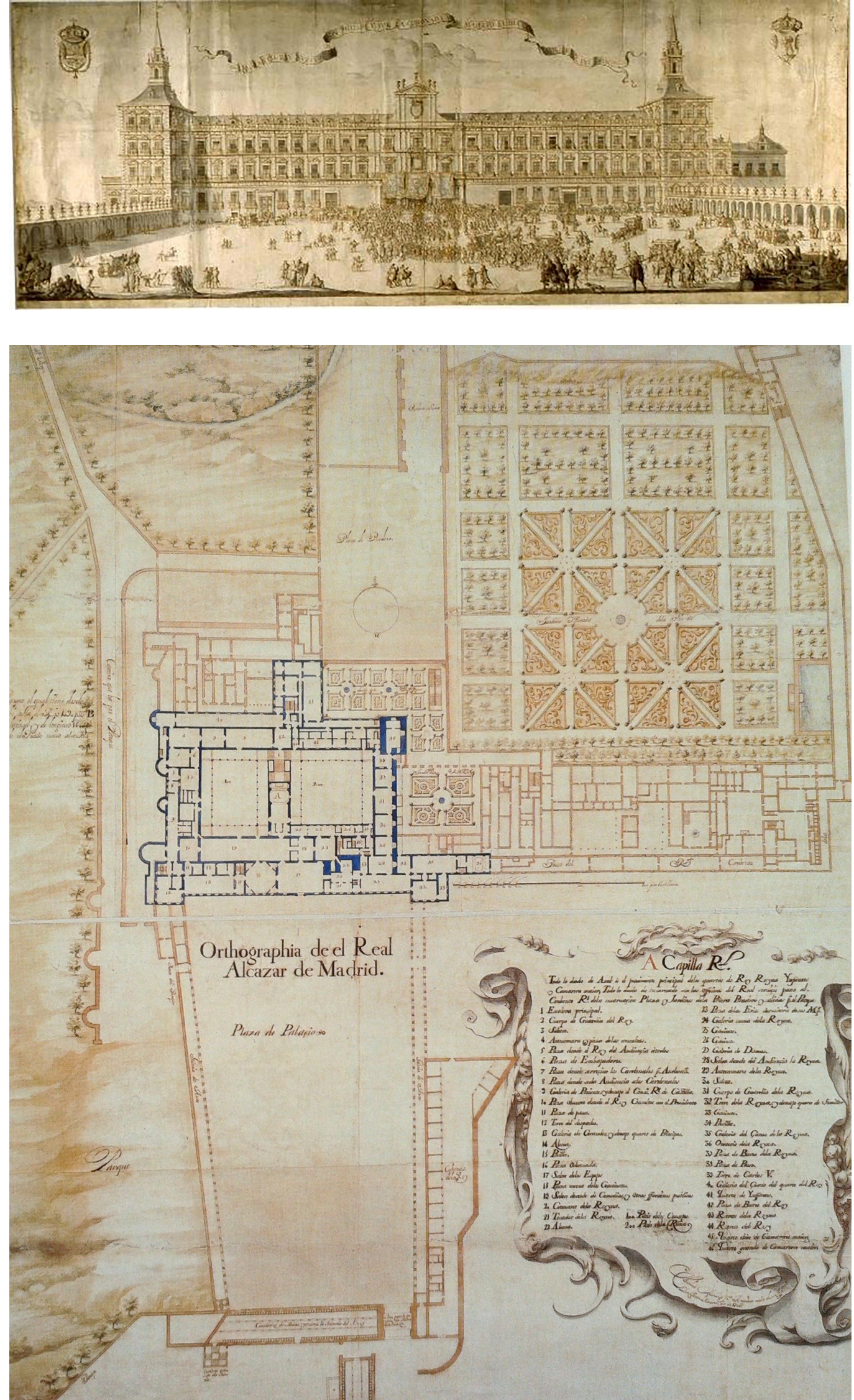
Patrizio de Orvieto by Antonio di Sangallo, I527-I537-, and the one in the cittadella di Torino (fig. 6).

In the surrounding urban quarters, some new streets were traced -as Platerias- the Medieval urban spaces were regularized, and many bridges were built over the Manzanares river on the main roads (fig. 7).

The kings of the Bourbon dynasty kept their residence in the old Alcázar until a fire burnt it down on Christmas Eve 1734, and a new baroque-classicist palace was built. The first project was soon commissioned by King Philip V and Queen Isabel de Farnesio to the Italian architect Filippo Juvarra in 1735, who designed a huge horizontally arranged building that, due to their dimensions, should have been built some $400 \mathrm{~m}$ to the north (fig. 8).

Fig. 6. Giovanni Battista Sacchetti, Cross section of the ramps to the Royd Parc, 1757. Archivo General de Palacio, Palacio Real, Madrid.

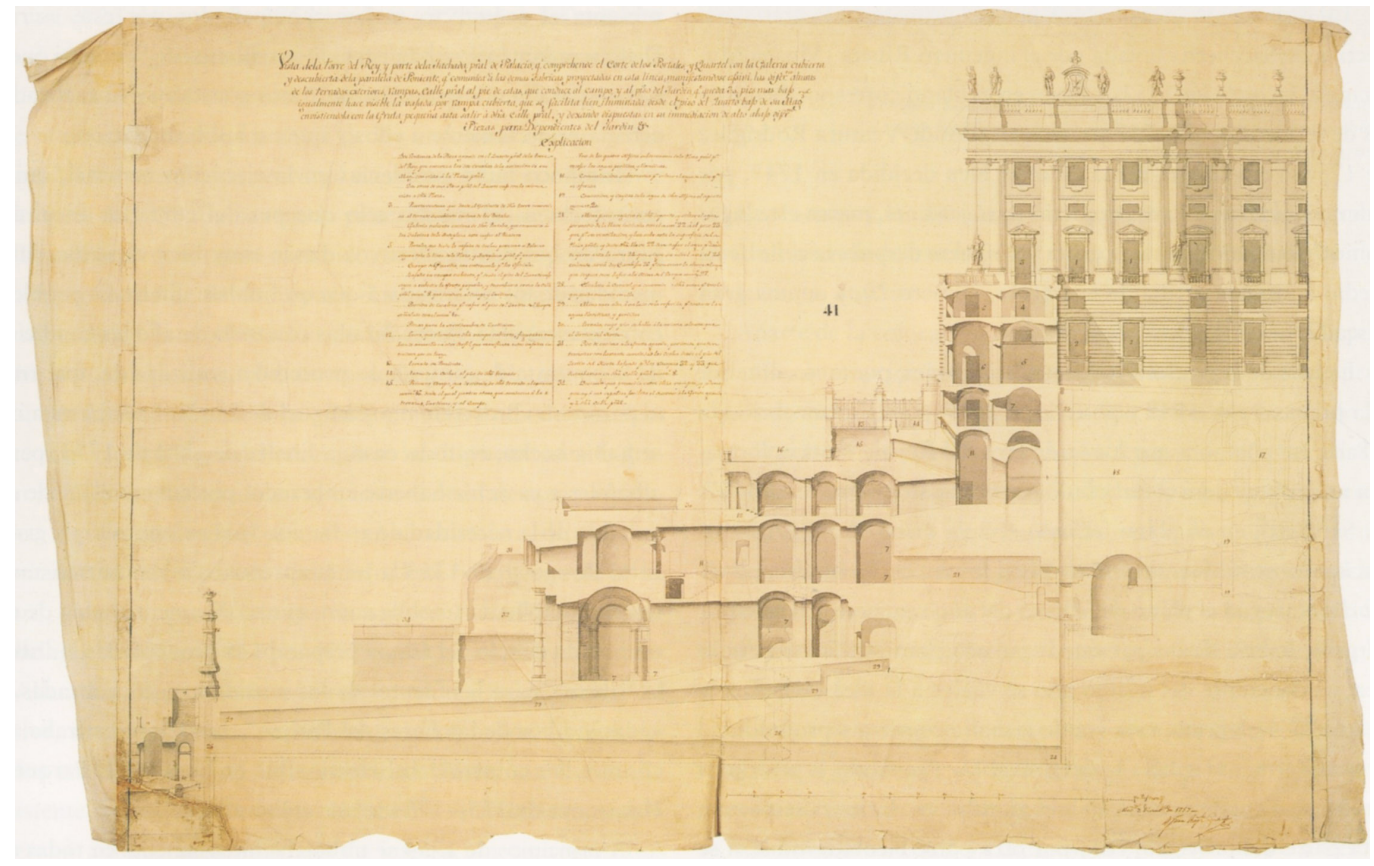

But Juvarra died in January 1736 in Madrid, and his disciple Giovanni Battista Sacchetti became the responsible of the project. Eventually, the monarchs decided to construct the new palace or Palacio Real Nuevo on the site of the former Alcázar, but with a vertical configuration. Sacchetti adapted his master's design and transformed the first draft into a high-rise compact building that would be able to accommodate both the royal family and the government administrative offices. Architect Francesco Sabatini, who had worked with Juvarra on the construction of the Palazzo Reale in Caserta, was also called to collaborate with Sacchetti (fig. 9).

Richard Twiss, who visited the new palace in 1775, considered that it "probably was the biggest and most luxurious in Europe", keeping the centrality with respect of the Royal estates and the Royal Sites that were being built around Madrid.

Many interesting urban projects were developed along the $18^{\text {th }}$ and the $19^{\text {th }}$ centuries in the surroundings of the Palacio Nuevo, mainly on the areas of the Plaza de Oriente to the east, and Plaza de Armas to the south. A large number of existing buildings and public spaces were demolished and reshaped, while the rugged topography towards the neighbouring Segovia Street was the subject of successive viaduct proposals (fig. I0).

Other initiatives looked for new designs for the areas of La Tela and Campo del Moro lying west of the Palace, in order to build new gardens and to communicate them with the plateau of the Plaza de Armas, bridging a height difference of more than $60 \mathrm{~m}$.

Finally, the exile of King Alphonse XIII in 193I required an essential change in the design, character and management of the royal properties. For instance, the huge royal gardens 


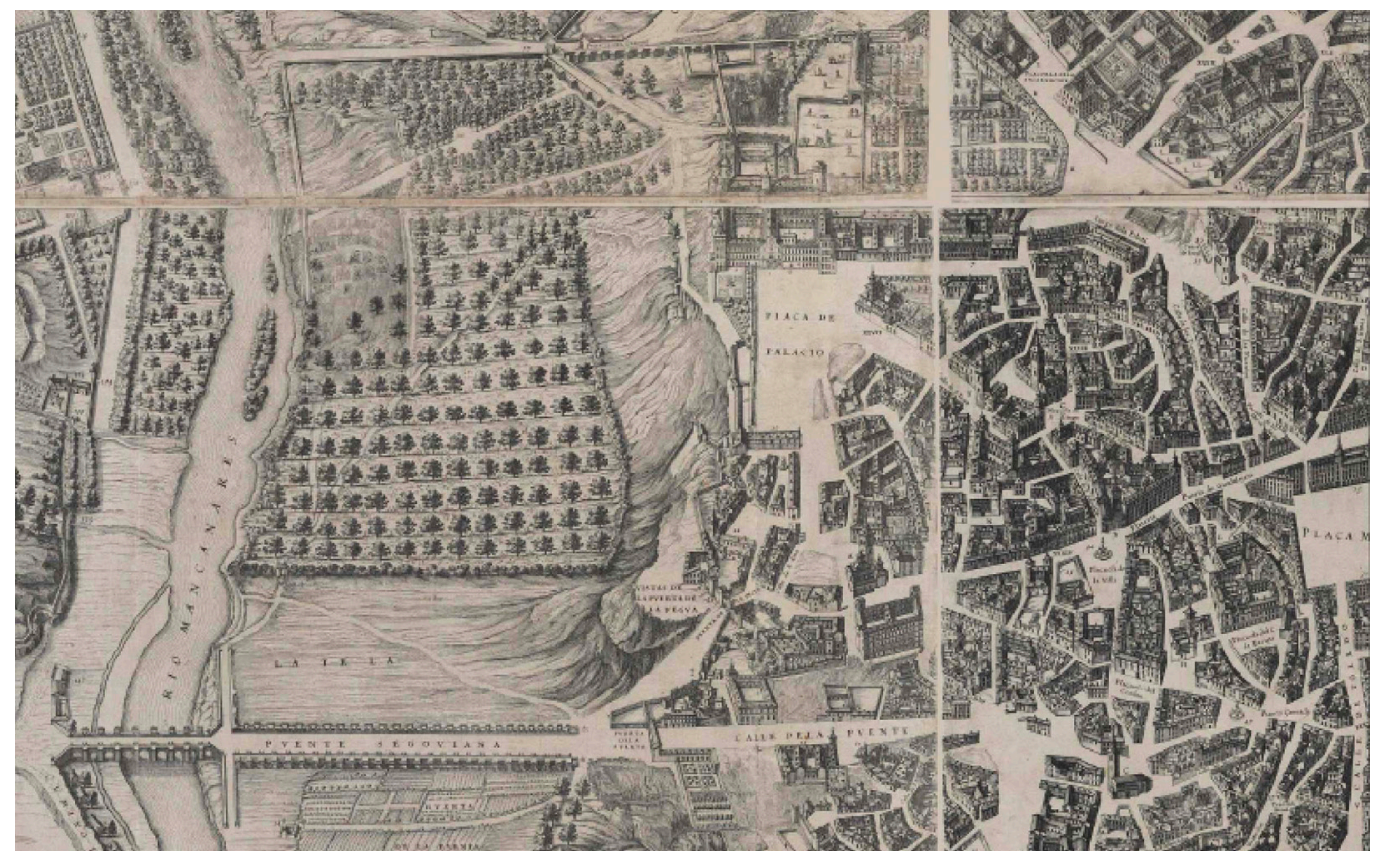

became of public use, and the royal stables were demolished to enlarge the gardens and align the adjacent streets.

The new Sabatini Gardens were designed by the famous architect and urban planner Fernando García Mercadal during the Second Spanish Republic, at the end of the time frame defined for our research. All these projects changed substantially the urban landscapes in the vicinity of the Royal Palace, whose preservation is entrusted to Patrimonio Nacional and to Madrid City Council (fig. II).

Fig. 8. Filippo Juvarra, Longitudinal section of the main staircase and the Chapel, project for the New Royal Palace in Madrid, 1735 c. Biblioteca Nacional de España, Madrid.

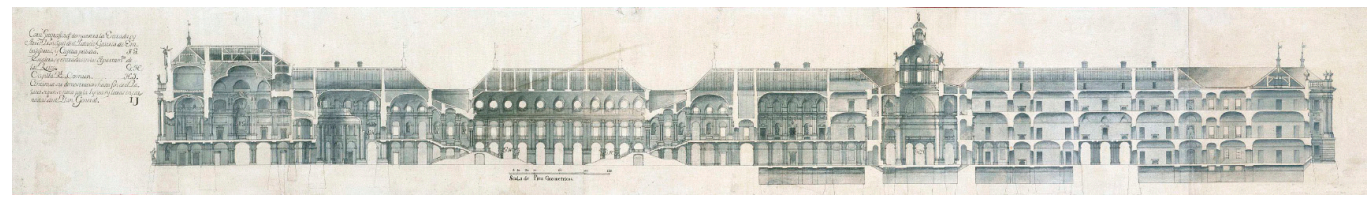

\section{Conclusions and prospective}

The main target of our research deals with the reconstruction of the historical landscapes surrounding the Royal Palace in Madrid, recovering the memory of the territories. To this end we provide an essential knowledge to be taken into account before undertaking every architectural or urban project in the area.

As a way to manage and disseminate all the information, the next phases of our research will structure datasets into multiformat databases in order to implement a Geographic Information System (GIS) on a digital cartographic basis at a scale 1:2,000.

By means of a Digital Terrain Model (DTM), we will build the visual shells from the most frequent points of view that are used in the historic images in each period, as well as from others that are able to show the qualities of the existing, planned and faded urban spaces and landscapes. 
Fig. 9. Western façade of the Royal Palace to the Campo del Moro.

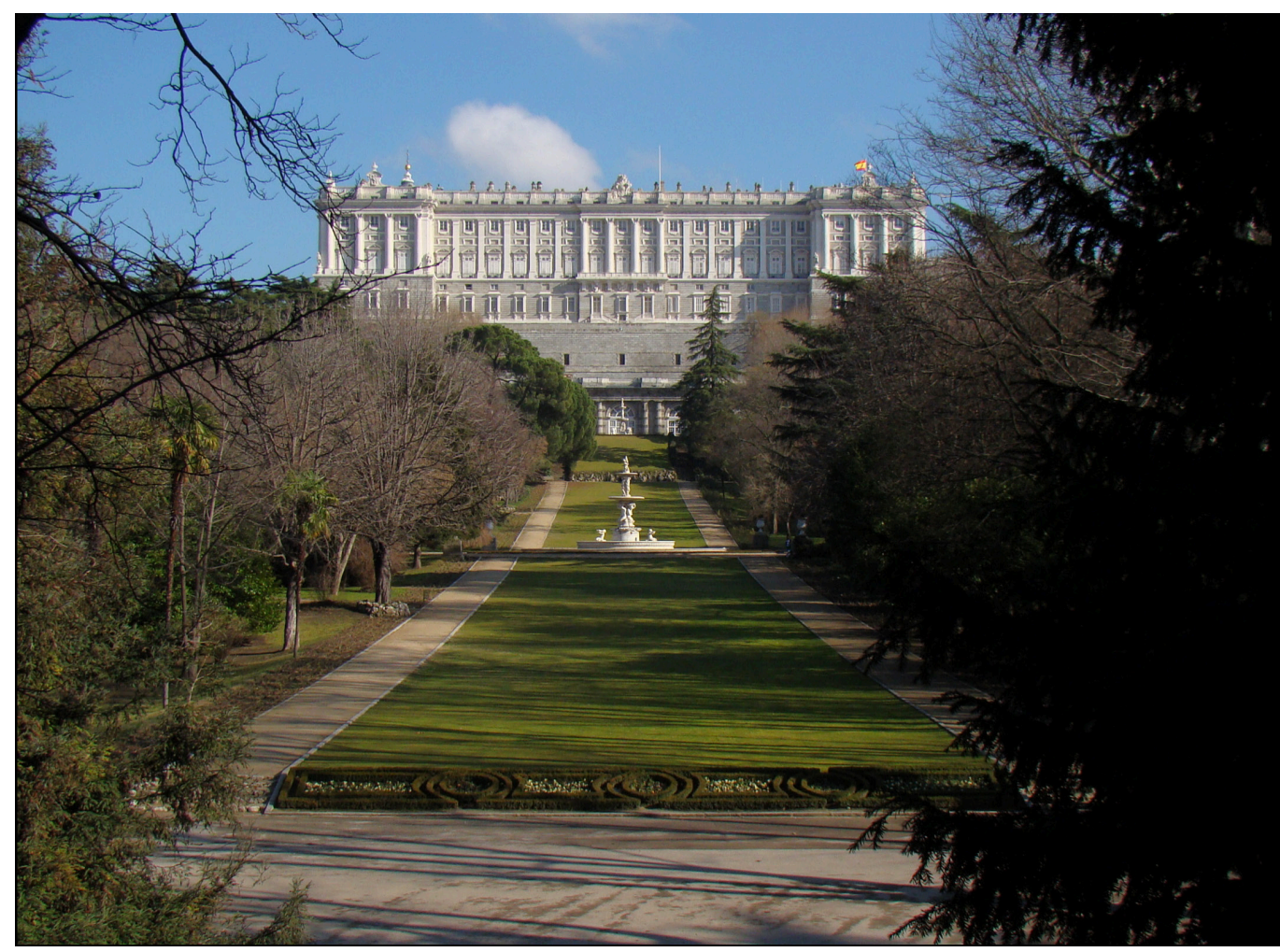

Fig. 10. Silvestre Pérez Master plan for the

surroundings of the Royal Palace and the quarter of San Francisco, I 810. Biblioteca Nacional de España, Madrid.

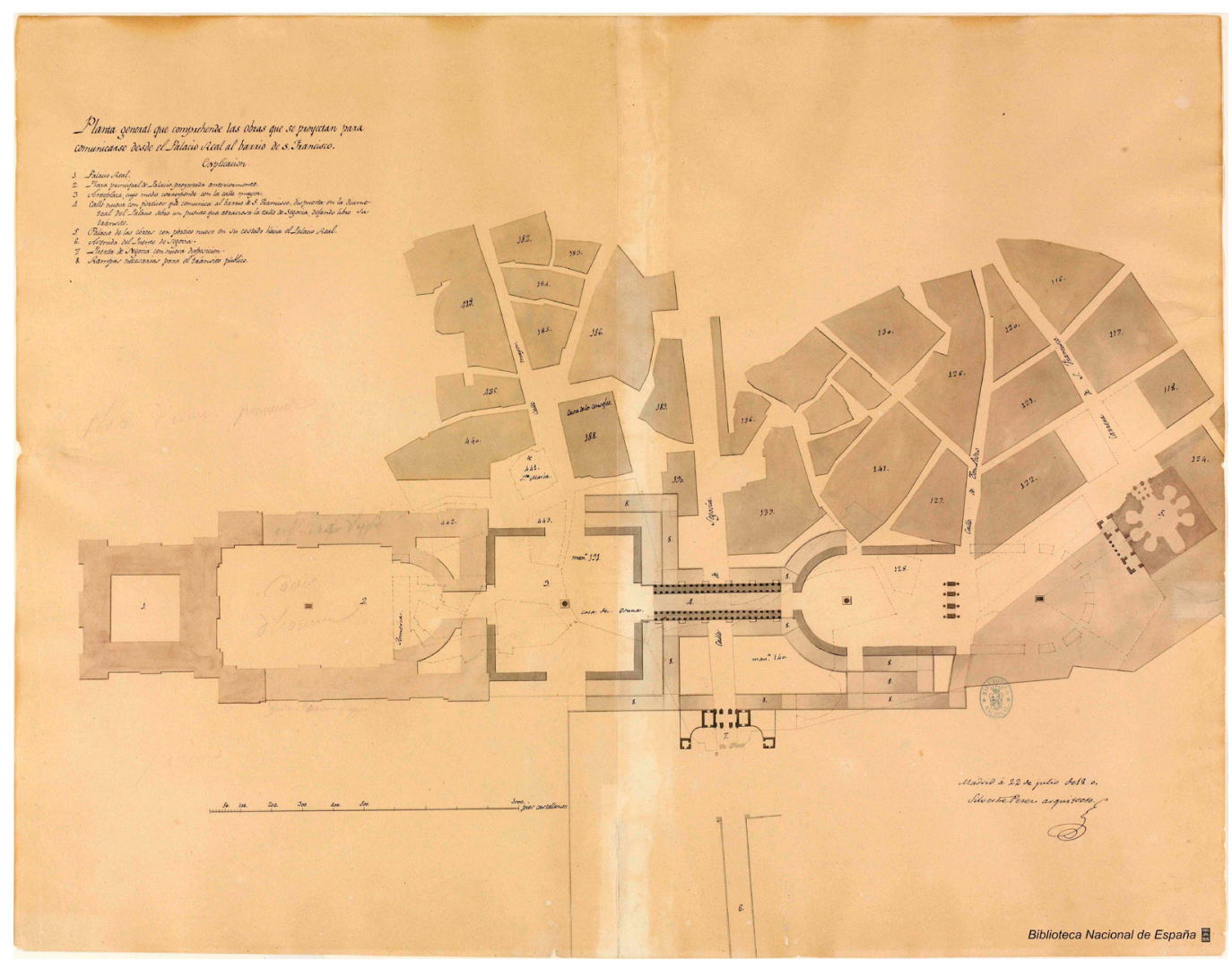


Fig. I I. Fernando García Mercadal, Garden Project for the National Palace, From: Revista del Colegio Oficial de Arquitectos, n. 8, 1935.

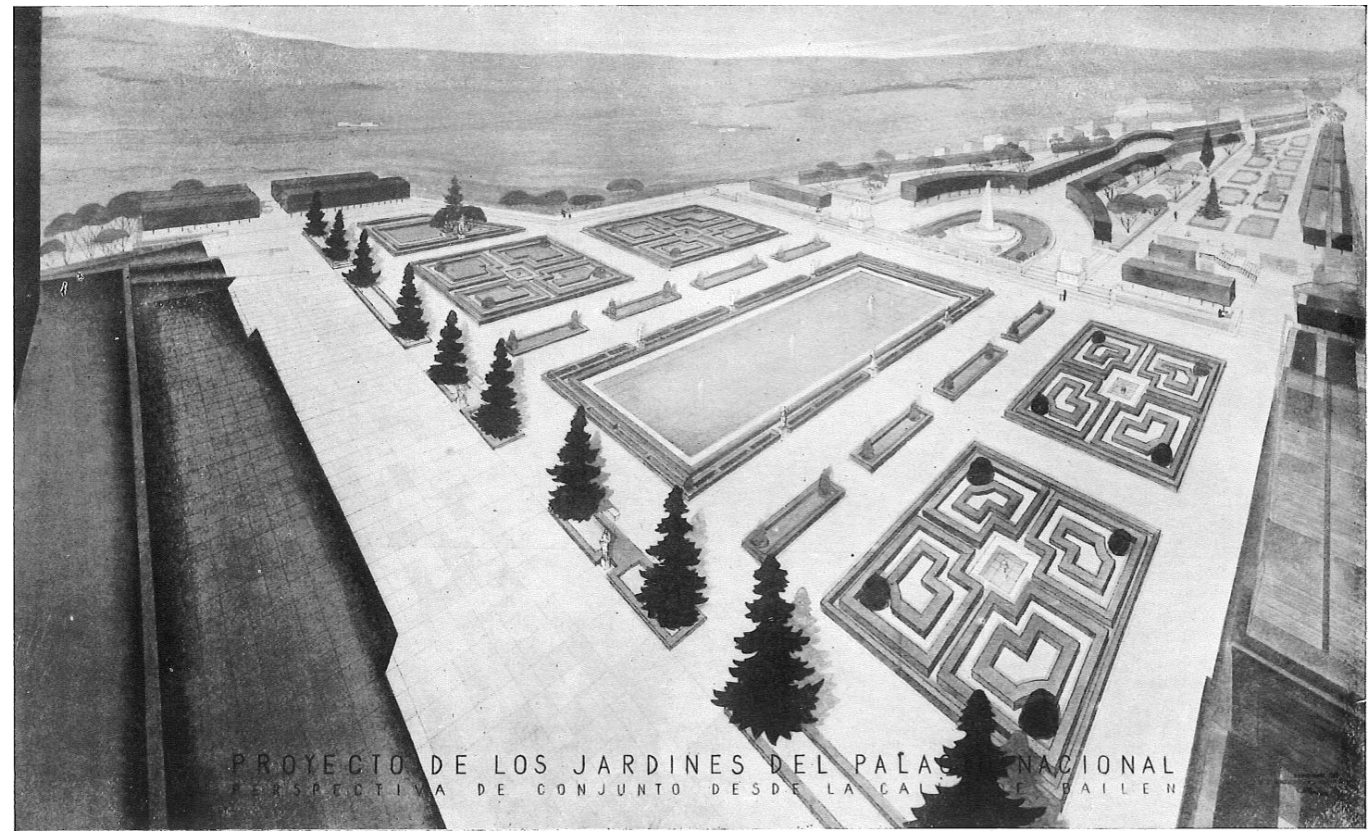

\section{References}

Bianchini $C$ et al (2020). La costruzione scientifica della memoria: il caso della nuova antica cittá di Ninfa. En A Arena et a (a cura di). Connettere/Connecting. Un disegno per annodare e tessere/Drawing for weaving relationships. Atti del $42^{\circ}$ Convegno Internazionale dei Docenti delle Discipline della Rappresentazione/Connecting. Languages Distances Technologies. Proceedings of the $42^{\text {th }}$ International Conference of Representation Disciplines Teachers. Milano: Franco Angeli, pp. 1760 - 1777.

Centofanti M. et al. (2008). II progetto del SIARCH - UNIVAQ, Sistema Informativo Architettonico. En R. Mingucci, M. Centofanti (a cura di). DisegnareCon, Conservazione del Patrimonio Architettonico e Urbano, n. I (2), pp. I-7.

Chías P. (20 I 7). Complejidad y contradicción en el urbanismo de Fernando García Mercadal. En Academia, n. 3, pp. 22 I-236.

Chías P. (2019). Building territories and landscapes: the essential knowledge of a forgotten cultural heritage. En IMG Journal. 05/0 I, pp. 92-105.

Chías P., Abad T. (2016). La transformación de la topografía y del paisaje en la construcción del Monasterio de El Escorial. En Informes de la Construcción. 68/543, pp. I-12.

Chías P., Abad T. (20 I 8). Drawings and scale models used in building the Spanish royal sites. En Diségno, n. 2, pp. 33-42.

Chías P., AbadT. (2019a). Maps and Drawings of the Royal Sites around the Guadarrama Mountain Range. En Revista EGE. I I, pp. 44-63.

Chías P., AbadT. (20 I 9b). Building territories and landscapes at the Royal Site of Aranjuez. En Diségno, n. 5, pp. 8I-90.

Chías P., Abad T. (2019c). La cartografía y otras fuentes gráficas para el conocimiento del territorio y del paisaje. Los Reales sitios en torno a Madrid. En CT Catastro, n. 96, pp. I I-42.

Chías P., AbadT. (202 l a). Fuentes cartográficas para el conocimiento de los territorios de los Reales Sitios. El caso de Aranjuez 1775-1912. En Los Libros de la Corte, 22, pp. I I-42.

Chías P., AbadT. (202 l b). Fuentes cartográficas para el conocimiento de los territorios de los Reales Sitios. El caso de Aranjuez, 1775-1912. En Jiménez Castillo, J., Rivero Rodríguez, M. (coords.) De Reinos a Naciones. Espacios, territorios y mentalidades. Colección La Corte en Europa, 2 1. Madrid: Polifemo, 25 I-299.

Chías P., Papa L. M. (a cura di). (2019). Disegnarecon. Drawing the territory and the landscape.Vol. I 2, n. 22.

Corniello L. (2019). II disegno del Parco Reale di Tirana. Napoli: La Scuola di Pitagora editrice.

Cundari C., Carnevali L. (a cura di). (2003). Il rilevamento urbano: tipologia, procedure, informatizzazione. Roma: Kappa edizioni.

De Marco R., Dell'Amico A. (2020). Connettere il territorio tra patrimonio e informazione: banche dati e modelli per le Cultural Heritage routes. En A. Arena et al. (a cura di). Connettere/Connecting. Un disegno per annodare e tessere/Drawing for weaving relationships. Atti del $42^{\circ}$ Convegno Internazionale dei Docenti delle Discipline della Rappresentazione/Connecting. Languages Distances Technologies. Proceedings of the $42^{\text {th }}$ International Conference of Representation Disciplines Teacher. Milano: Franco Angeli, pp. 2058-2077.

Ford R. ( I 845). A handbook for travelers in Spain and readers at home. London: John Murray, Albermarle Street. 
Gérard V. (1976). Les problémes artistiques de l'Alcázar de Madrid (I537-1700). Mélanges de la Casa de Velázquez, t. XII, pp 307-322.

Giandebiaggi P.,Vernizzi C. (2020). Gli organismo religiosi nella trasformazione della cittá europea: dal rilievo alla definizione di una identitá urbana. En A. Arena et al (a cura di). Connettere/Connecting. Un disegno per annodare e tessere/Drawing for weaving relationships. Atti del $42^{\circ}$ Convegno Internazionale dei Docenti delle Discipline della Rappresentazione/Connecting. Languages Distances Technologies. Proceedings of the $42^{\text {th }}$ International Conference of Representation Disciplines Teacher. Milano: Franco Angeli, pp. ||6|-||82.

Luschi C. M. R., Aiello L. (2020). La ricostruzione storica della città attarvetrso l'iconografia urbana. Il caso studio di San Giovanni d'Acri. En A. Arena et al (a cura di). Connettere/Connecting. Un disegno per annodare e tessere/Drawing for weaving relationships. Atti del $42^{\circ}$ Convegno Internazionale dei Docenti delle Discipline della Rappresentazione/Connecting. Languages Distances Technologies. Proceedings of the $42^{\text {th }}$ International Conference of Representation Disciplines Teacher. Milano: Franco Angeli, pp. $2369-2382$.

Mandelli E., Duvernoy S. (2002) (a cura di). Il disegno della città: opera aperta nel tempo. Atti del Convegno internazionale AED. San Gimignano 28-30 giugno 2002. Firenze: Alinea.

Martínez A. (2008). Espacio, tiempo y proyecto: El entorno urbano del Palacio Real Nuevo de Madrid entre 1735 y 1885 . Madrid: Ayuntamiento de Madrid.

Mesonero Romanos R. (|86|). El antiguo Madrid: paseos histórico-anecdóticos por las calles y casas de esta villa. Madrid: Establecimiento Tipográfico de Don F. de P. Mellado.

Papa M. L., D'Agostino P. (2020). Un proceso integrato di conscenza e visualizzazzione. II castello della Reggia di Portici. En A. Arena et al (a cura di). Connettere/Connecting. Un disegno per annodare e tessere/Drawing for weaving relationships. Atti del $42^{\circ}$ Convegno Internazionale dei Docenti delle Discipline della Rappresentazione/Connecting. Languages Distances Technologies. Proceedings of the $42^{\text {th }}$ International Conference of Representation Disciplines Teacher. Milano: Franco Angeli, pp. 25 I 5-2532.

Pérez Galdós B. ( 884$)$. La de Bringas. Madrid: Imp. y Lit. de La Guirnalda.

Ponz A. ( I776- I794). Viage de España en que se dá noticia de las cosas más apreciables, y dignas de saberse, que hay en ella, Tercera edición, 18 vols., Madrid: Por D. Joachin Ibarra.

Sancho J. L. (1988). Notas sobre la herencia de Vanvitelli en la obra de Palacio. En Actas del Congreso Internacional Carlos III y la Luis Ilustración. Madrid: Ministerio de Cultura.

Sancho J. L. (1995). La arquitectura de los Sitios Reales. Catálogo histórico de los palacios, jardines y patronatos reales del Patrimonio Nacional. Madrid: Patrimonio Nacional, Fundación Tabacalera.

Sancho J. L. (20 I5). Palacio Real de Madrid. Madrid: Patrimonio Nacional.

Sand G. ( 1 854- 1857). Histoire de ma vie.Vols. I0. Paris:Victor Lecou, Éditeur / Michel Lévy Fréres, Libraires.

Twiss R. (1775). Travels through Portugal and Spain, in 1772 and 1 773. London: Printed for the Author and sold by G. Robinson, T. Becket, and J. Robson.

Vernizzi C., Bontempi D. (2015). La rappersentazione della città per lo stuio dei fenomeni urbani. Evoluzione metodológica attraverso casi studio. En A. Marotta, G. Novello, (a cura di). Disegno \& Città: cultura, arte, scienza, informazione. Atti del $37^{\circ}$ Convegno Internazionale dei Docenti delle Discipline della Rappresentazione. Torino 17-19 settembre 20 I5, pp. 87 I-878. Roma: Gangemi Editore.

\section{Authors}

Pilar Chías Navarro, Universidad de Alcalá, pilar.chias@uah.es

Tomás Abad, Universidad de Alcalá, tomas.abad@uah.es

To cite this chapter: Chías Navarro Pilar, Abad Tomás (2021). La construcción de los paisajes del palacio real de madrid, Siglos XVI-XX/Planned and built landscapes around the Palacio Real in Madrid, $16^{\text {th }}$ to $20^{\text {th }}$ Centuries. In Arena A., Arena M., Mediati D., Raffa P. (a cura di). Connettere. Un disegno per annodare e tessere. Linguaggi Distanze Tecnologie. Atti del $42^{\circ}$ Convegno Internazionale dei Docenti delle Discipline della Rappresentazione/ Connecting. Drawing for weaving relationship. Languages Distances Technologies. Proceedings of the $42^{\text {th }}$ International Conference of Representation Disciplines Teachers. Milano: FrancoAngeli, pp. 432-45।. 